\title{
Diversity patterns of aquatic macroinvertebrates in a tropical high-Andean catchment
}

\author{
Rodrigo Espinosa ${ }^{1,2 *}$, Patricio Andino을 Sophie Cauvy-Fraunié 3 , Olivier Dangles ${ }^{4}$, \\ Dean Jacobsen ${ }^{5}$ \& Verónica Crespo-Pérez ${ }^{1 *}$
}

1. Laboratorio de Limnología, Museo de Zoología QCAZ I, Escuela de Ciencias Biológicas, Pontificia Universidad Católica del Ecuador, Av. 12 de Octubre 1076, Apartado: 17-01-2184, Quito, Ecuador; mvcrespo@puce.edu.ec, pj.andino.guarderas@gmail.com, reespinosaro80@gmail.com

2. Grupo de Biogeografía y Ecología Espacial - BioGeoE2, Facultad de Ciencias de la Vida, Universidad Regional Amazónica Ikiam, Km 7 Vía Muyuna, Tena, Ecuador; rodrigo.espinosa@ikiam.edu.ec

3. INRAE, UR RIVERLY, Centre de Lyon-Villeurbanne, Villeurbanne Cedex, France; sophie.cauvy-fraunie@inrae.fr

4. Centre d'Ecologie Fonctionnelle et Evolutive, UMR 5175, CNRS, Université de Montpellier, Université Paul Valéry Montpellier, EPHE, IRD, Montpellier, France; olivier.dangles@ird.fr

5. Freshwater Biological Section, Department of Biology, University of Copenhagen, Copenhagen, Denmark; djacobsen@bio.ku.dk

* Correspondence

$$
\text { Received 19-X-2019. Corrected 07-VIII-2020. Accepted 31-VIII-2020. }
$$

\begin{abstract}
Introduction: Glacierised catchments are remote and hostile environments, in which streams from different water sources (e.g., glacier melt, rain/snowmelt, groundwater) converge, creating a complex mosaic of stream sites with varying levels of glacial influence and environmental conditions. This environmental heterogeneity, in turn, influences the assemblage and composition of aquatic communities and produces complex patterns of species diversity at the catchment scale. Objectives: In this contribution, we assessed biodiversity and community composition of aquatic macroinvertebrate communities from 51 stream site types in a glacierised catchment in the tropical Andes. The aim of our study was to: (1) determine diversity, rarity, commonness and spatial distribution patterns of aquatic macroinvertebrate communities from sites with different water sources, and (2) identify which environmental variables influence the density and presence of macroinvertebrate taxa and, in particular, of the subfamilies of the ubiquitous chironomids. Methods: Our study sites were grouped according to their water source and to their percentage of glacier coverage in the catchment (GCC). At each site we sampled aquatic macroinvertebrates, measured environmental variables and assessed community differences and environmental influence with ordination analyses and generalized linear models. Results: Kryal and mixed sites had an important proportion of rare taxa. Mean richness was highest in the mixed sites and lowest in the sites with the highest glacier cover; while sites with an intermediate percentage of glacier cover, had the highest values of $\alpha$ and $\beta$ diversity. We found that 13 taxa $(15.9 \%)$ were common to all stream site types. SIMPER analysis showed that Orthocladiinae, Hyalella sp. and Andesiops sp. contributed the most to the dissimilarity between site types ( $>45 \%$ of cumulative contribution). RDA showed that kryal sites were associated with high turbidity and density of Podonomids, and with low temperature, amount of CPOM and densities of both Anomalocosmoecus sp. and Andesiops sp. Orthocladinae was associated with high current velocity and chlorophyll $a$ concentration, whereas Hyalella sp. had a positive relationship with higher $\mathrm{pH}$ and streambed stability. Generalized linear models showed that GCC was the main variable explaining all faunal metrics. Current velocity explained macroinvertebrate abundance, water temperature was related to chironomid density and chlorophyll $a$ influenced Orthocladiinae presence-absence. Conclusions: Our results suggest that by favoring the presence of rare taxa and taxa turnover, glacier influence may increase biodiversity in glacierised
\end{abstract}

Espinosa, R., Andino, P., Cauvy-Fraunié, S., Dangles, O., Jacobsen, D., \& Crespo-Pérez, V. (2020). Diversity patterns of aquatic macroinvertebrates in a tropical high-Andean catchment. Revista de Biología Tropical, 68(Suppl. 2), S29-S53. 
catchments. In terms of biodiversity conservation, this study confirms an urgent need to increase knowledge of high-Andean stream biodiversity, especially in highly heterogenous glacierised catchments, to better describe regional biodiversity patterns and community composition of these highly vulnerable freshwater ecosystems. Detailed analyses of benthic communities and development of databases are key for conservation strategies. Water management municipalities and/or enterprises should consider water quality and stream types for more sustainable management of these important ecosystems.

Keywords: aquatic macroinvertebrates; glacierised catchments; krenal; kryal; rarity; rhithral.

Glacierised catchments harbor streams from different water sources, such as glacierfed (kryal), rainfall/snowmelt-fed (rhithral) and groundwater-fed (krenal) streams (Füreder, 1999; Brown, Hannah \& Milner, 2003), whose confluence creates a complex mosaic of reaches with varying levels of glacial influence and environmental conditions. This, in turn, influences the assemblage of local aquatic communities and produces complex patterns of species diversity and composition at the catchment scale. Glacier-fed streams, in particular those closer to glaciers, are expected to produce strong niche selection, because harsh environmental conditions filter non-tolerant species from the regional pool (Chase, 2007). This should produce communities with a more predictable composition and higher proportions of rare taxa, than those from less extreme habitats located farther away from the glacier snout (Leibold et al., 2004; Chase, 2007; Jacobsen et al., 2012). Several studies on glacier-fed streams around the world have found that taxonomic and functional diversity decrease with increasing glacial influence (Milner \& Petts, 1994; Milner et al., 2001a; Jacobsen et al., 2010; Jacobsen \& Dangles, 2012; CrespoPérez et al., 2020), probably due to lower water temperature, and higher turbidity, hydrologic instability, and streambed disturbance closer to the glaciers (Milner et al., 2001a; Crespo-Pérez et al., 2020). Other studies have revealed peaks in local richness at intermediate levels of glacier influence, (Jacobsen et al., 2012; CauvyFraunié et al., 2014a; Quenta et al., 2016), and more diversified communities at the confluences of streams with different water sources (e.g., kryal-rhithral, rhithral-krenal) (Lencioni, Rossaro \& Maiolini, 2007).

Commonness, rarity and taxa turnover rates have been the central focus of various ecological studies around the world (e.g., Kunin \& Gaston, 1993; Cao, Larsen \& Thorne, 2001; Alahuhta et al., 2014; Gibson-Reinemer, Sheldon \& Rahel, 2015). Commonness is defined as the antagonistic definition of uncommon or rare, where rarity can be categorized in two different ways: (1) by total abundances and (2) by occurrence or occupancy in the samples (Josefson, 2009). Lately, with ongoing climate change, and glacial retreat, there has been increased interest in the study of levels of commonness and rarity in invertebrate and microbiota communities in glacierised catchments (e.g., Wilhelm et al., 2014; Robinson et al., 2016; Lencioni, 2018; Alther et al., 2019). Although common species are thought to be more habitat generalists and occur in higher abundances, there has been no consensus in the underlying processes that make species common or rare (Alahuhta et al., 2014). Some studies suggest that there are no strong differences in the mechanisms that make species rare or common at a regional scale (Heino \& Soininen, 2010; Siqueira et al., 2012). Others propose that commonness and rarity depend on niche differentiation (Rabinowitz, Rapp \& Dixon, 1984; Cucherousset et al., 2008), whereas another group of studies propose that rarity is associated with dispersal abilities and colonization dynamics among species (Kunin \& Gaston, 1993; Resh, Bêche \& McElravy, 2005). In the case of aquatic macroinvertebrates, and particularly the highly adapted dipteran 
family Chironomidae, Robinson et al. (2016) found highly diverse and spatially-structured assemblages with higher levels of rarity in mountain catchments. There is speculation that the insularity of high mountain catchments and the harsh environmental conditions associated with glacial influence may be the cause of this high degree of rarity often found in headwater streams (Lencioni, 2018).

In this study we examined local $(\alpha)$ and among site $(\beta)$ diversity of benthic macroinvertebrate communities, as well as environmental instream conditions in 51 stream site types in a glacierised catchment of the tropical Andes. We used the same macroinvertebrate database as Cauvy-Fraunié et al. (2015) to answer the following questions: (1) are macroinvertebrate diversity, rarity, commonness and spatial distribution patterns different among site types with different water sources? (2) which environmental variables influence the density and presence of macroinvertebrate taxa, and in particular of the subfamilies of the ubiquitous chironomids? We predicted that, compared to the other stream site types, glacier-fed sites would shelter a higher proportion of rare and specialized taxa adapted to the harsh local conditions. We also expected that environmental variables associated with glacial meltwater, such as turbidity, water temperature, conductivity, and physical stability would influence the distribution and density of freshwater macroinvertebrates and of chironomids in particular. Understanding such diversity patterns could yield important information, useful for designing effective management and/or conservation strategies for these highly threatened ecosystems.

\section{MATERIALS AND METHODS}

Study area: The study was conducted at 51 sites located in the western slopes of Mt. Antisana, located in the eastern cordillera of the Ecuadorian Andes $\left(0^{\circ} 28^{\prime} \mathrm{S}, 78^{\circ} 09^{\prime} \mathrm{W}, 5760\right.$ m.a.s.1.), c. $50 \mathrm{~km}$ south of the equator. All sites are tributaries of the Río Antisana, headwater of the Napo River, a main tributary of the upper Amazon River. All study sites were located between 3886 m.a.s.l. and 4835 m.a.s.l., at distances from $15 \mathrm{~m}$ to $15.2 \mathrm{~km}$ from the glacier snouts of Mt. Antisana (Fig. 1). For additional

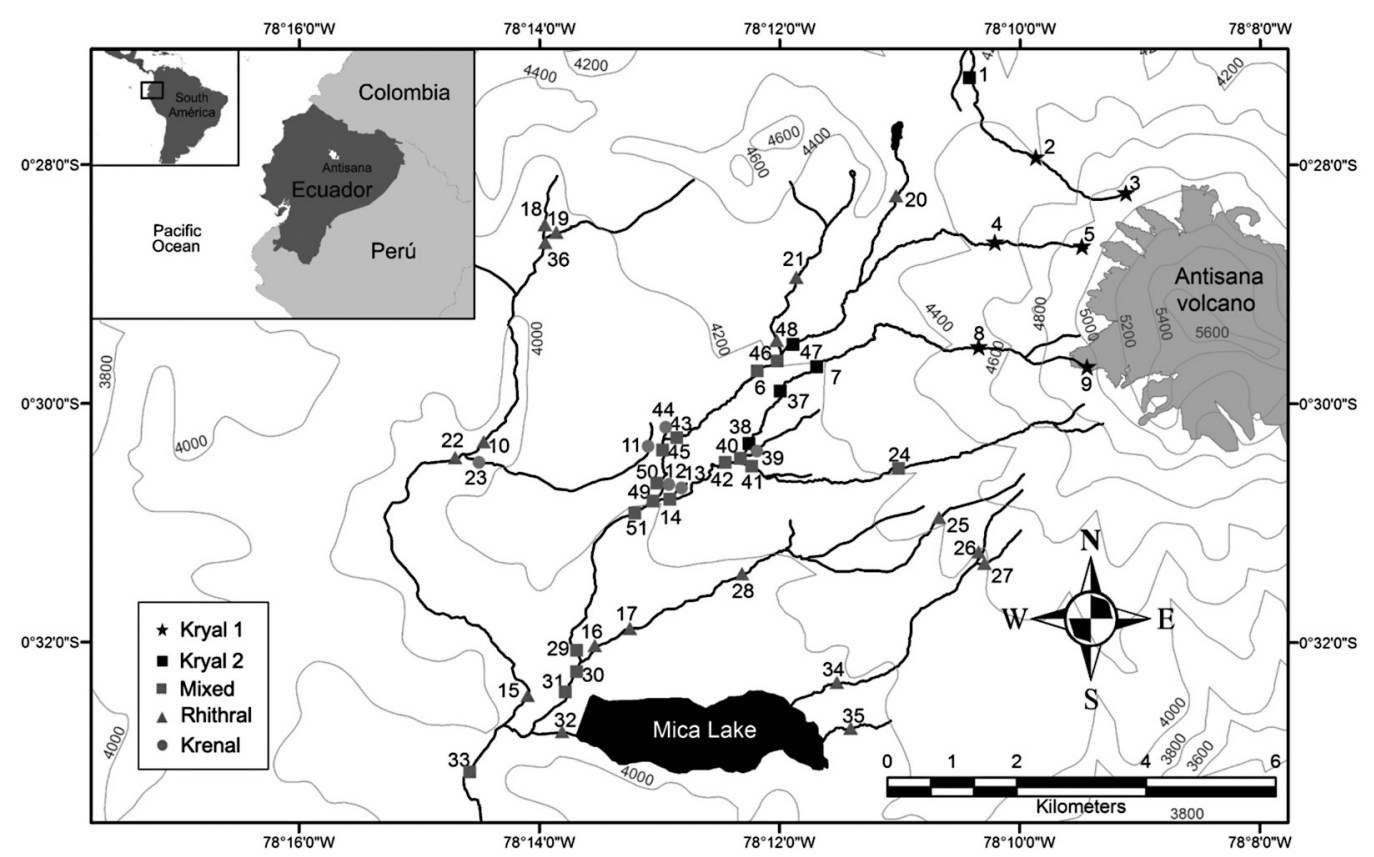

Fig. 1. Topographic map of the study area with 51 study stream site types. 
information on the study area see CauvyFraunié et al. (2015).

Following Brown et al. (2003), stream sites were first divided into three main groups, depending on their origin: kryal (glacier meltdominated streams), krenal (groundwater-fed streams), and rhithral (seasonal rain and snowmelt-fed streams). We then applied a sub-classification - based on the percentage of glacier cover in the catchment (GCC) (Füreder, 2007; Milner et al., 2009) - to all sites with glacier melt water influence, and to those resulting from the confluence of streams with different water sources (see Cauvy-Fraunié et al., 2014a for details on GCC calculation). Kryal sites originated from three glaciers on the western side of Mt. Antisana: glacier 12, also called Crespo, with an extension of $1.82 \mathrm{~km}^{2}$, in 2010; glacier 14, with an extension of 1.24 $\mathrm{km}^{2}$, in 2011; and glacier 15, with an extension of $0.60 \mathrm{~km}^{2}$, in 2010 . We divided kryal sites into two groups: kryal 1 (K1) sites were located between 4520-4835 m.a.s.l. and had the highest percentages of GCC (mean $=68 \%$, range $=39-93 \%)$. Kryal 2 (K2) sites consisted of five sites between 4 109-4 332 m.a.s.l. and had a GCC of 17 to $27 \%$ (mean $=23 \%)$. We included 18 rhithral and six krenal sites, which were located between $3917-4368$ and 4 0064124 m.a.s.l., respectively, and had no glacial influence. The mixed sites (M), included 16 sites located between 3 930-4 246 m.a.s.l., with 1 to $18 \%$ GCC $($ mean $=8 \%)($ Fig. 1 , Table 1$)$.

Environmental variables: In all sites, on the same dates of macroinvertebrate sampling (see below), water temperature $\left({ }^{\circ} \mathrm{C}\right)$, conductivity (at $25^{\circ} \mathrm{C}$ ), $\mathrm{pH}$, turbidity and the channel bottom component of the Pfankuch index (used to quantify the physical stability of the stream) were measured by Cauvy-Fraunié et al. (2015, see details therein). Autochthonous and allochthonous food resources available for macroinvertebrates were measured by quantifying chlorophyll $a$ (including phaeopigments) concentration in epilithic algae on randomly collected pebbles from each site and by calculating the weight of benthic detritus obtained in each Surber sample after the sorting of the animals (see Cauvy-Fraunié et al., 2015). Current velocity, stream slope, depth and width were measured by Crespo-Pérez et al. (2020, see details therein). For this study, on the same dates as measurements performed by CrespoPérez et al. (2020), we also characterized the stream bottom at three transects at each site. We estimated the number of substrate types, according to the Wentworth Scale (Giller \& Malmqvist, 1998): silt (0.004-0.062 mm), sand (0.063-2 mm), gravel $(2-16 \mathrm{~mm})$, pebble (16$64 \mathrm{~mm})$, cobble (64-256 mm), boulder (>256 $\mathrm{mm}$ ), and algae, macrophytes and/or moss (Supp. Table S1).

Macrobenthos sampling: Macroinvertebrate sampling was carried out at each site between May and October 2009 (i.e., during the dry season). At each site, five quantitative Surber samples $\left(500 \mathrm{~cm}^{2}\right.$; mesh size $\left.200 \mu \mathrm{m}\right)$ were collected randomly from pebble-cobble substratum in riffle/run habitats. Invertebrates were identified to morphospecies, genus,

TABLE 1

Summary of stream site characteristics for each site type. Values in parentheses correspond to min-max values and percentages

\begin{tabular}{lccccccc}
$\begin{array}{c}\text { Stream } \\
\text { Site } \\
\text { Types }\end{array}$ & $\begin{array}{c}\text { Number } \\
\text { of sites per } \\
\text { site type }\end{array}$ & $\begin{array}{c}\text { Stream } \\
\text { Order }\end{array}$ & $\begin{array}{c}\text { Mean Altitude } \\
\text { (m.a.s.1.) }\end{array}$ & $\begin{array}{c}\text { Mean Glacier } \\
\text { Cover in } \\
\text { Catchment }(\%)\end{array}$ & $\begin{array}{c}\text { Mean Distance } \\
\text { from Glacier (m) }\end{array}$ & $\begin{array}{c}\text { Unique Taxa } \\
\text { per site type }\end{array}$ & $\begin{array}{c}\text { Total } \\
\text { Common } \\
\text { Taxa }\end{array}$ \\
K1 & 6 & 1 & $4648(4520-4835)$ & $68(39-93)$ & $927(15-1847)$ & $2(2.4 \%)$ & \\
K2 & 5 & 1,2 & $4206(4109-4332)$ & $23(17-27)$ & $5573(3715-7189)$ & $2(2.4 \%)$ & 13 \\
M & 16 & $1,2,3$ & $4072.4(3930-4246)$ & $8(1-18)$ & $9048(3900-15183)$ & $8(9.8 \%)$ & $(15.9 \%)$ \\
Rhithral & 18 & $1,2,3$ & $4080.4(3917-4368)$ & - & - & $8(9.8 \%)$ & $4(4.9 \%)$ \\
Krenal & 6 & 1 & $4063.4(4006-4124)$ & - & - & 4 & \\
\hline
\end{tabular}


subfamily (in the case of Chironomidae) and family according to South American macroinvertebrate keys (Domínguez \& Fernández, 2009). For further details in macroinvertebrate sampling see Cauvy-Fraunié et al. (2015).

Data analysis: To describe biodiversity patterns across all five stream site types, we calculated two types of diversity levels: $\alpha$ and $\beta$. Alpha diversity (local diversity) was calculated as: (1) taxa richness (number of taxa); (2) the Shannon-Wiener (H) diversity index (based on the number of taxa corrected by their abundance), providing more information about community structure (including evenness) than a simple measure of richness (Magurran, 2013); (3) rarefied richness, using the minimum abundance across all sites (gives the expected species richness in random subsamples to correct for the density effect related to sampling imbalances); and (4) true diversity index (exponential Shannon) to convert the non-linearity characteristic of $\mathrm{H}$ to a linearized form, thereby allowing meaningful interpretations of the effective number of taxa (Jost, 2006). Shannon-Wiener, rarefied richness and true diversity indices were calculated in $\mathrm{R}$ software using the "vegan" package (version 3.6.3, R Development Core Team, 2020)

We used a multivariate approach to assess the spatial variation in community composition (i.e., Beta diversity). First, we tested similarity among two or more within-group dispersion matrices (Borcard et al., 2018) with two indices: Sorensen (presence-absence data) and Bray-Curtis (raw abundance data). To further understand how community composition changed among site types, we partitioned our multiple-site overall beta diversity (calculated with the Sorensen index) into two components: taxa replacement (i.e., taxa turnover) and nestedness (i.e., species loss or gain), with the poorest assemblage being a strict subset of the richest one (Baselga \& Orme, 2012). Finally, we evaluated differences in beta diversity components among site types, using analysis of variance, followed by Tukey's HSD post-hoc tests. These analyses were performed using the "betapart" package of R software (version 3.6.3, R Development Core Team, 2020). Differences in macroinvertebrate taxa relative abundance among site types were further assessed with an analysis of similarities (ANOSIM) (Chapman \& Underwood, 1999), which tested the null hypothesis that within-group similarity was equal to between-group similarity. To determine which macroinvertebrate taxa contributed the most to differentiating site types, we performed a similarity percentage analysis (SIMPER). ANOSIM and SIMPER analyses were ran using the Bray-Curtis distance measure and 9999 permutations, with the free software PAST (PAleontological STatistics, version 3.20).

To evaluate the influence of environmental variables on community structure we performed a Redundancy Analysis (RDA) and generalized linear models (GLM). Prior to these analyses, we excluded rare taxa (those occurring in only one sample), as well as those that accounted for less than $0.3 \%$ of the total species abundance. However, taxa with abundances less than $0.3 \%$ but commonly distributed (i.e., $>7$ sites) were retained (Skoulikidis, Karaouzas \& Gritzalis, 2009). Taxa with abundances exceeding $0.3 \%$, but occurring only in one or two sites were also excluded, in order to avoid bias caused by rare taxa (Legendre \& Legendre, 1998; Cao et al., 2001), or the 'dilution' of taxa that are uncommon and may influence statistical analysis. We also determined "rarity in abundance" by counting taxa with only one or two individuals at each site and "rarity in distribution" by counting taxa that were only present in one or two sites. Commonness was calculated as the number of taxa that were shared between all our site types. Before running RDAs we tested if our count data were suitable for linear ordination methods by testing their homogeneity with Detrended Correspondence Analysis (DCA) (Lepš \& Šmilauer, 2003). RDA computes axes that are linear combinations of the exploratory variables, in our case environmental variables, and preserves Euclidean distances among objects (Legendre \& Legendre, 1998). All correlated parameters $(r \geq 0.7)$ were 
excluded from the RDA, to reduce collinearity (Supp. Table S2). We ran the RDA on $\log 10$ $(\mathrm{x}+1)$ transformed environmental variables and on Hellinger transformed taxa density data, to reduce the effect of taxa with low counts and many zeroes. RDA analysis was performed with the "vegan" package of $\mathrm{R}$ (version 3.6.3, R Development Core Team, 2020).

The effect of instream environmental conditions on community diversity patterns (richness and density) was further examined with a generalized linear modeling (GLM) approach. We included 12 environmental predictors as candidate variables, after the removal of highly correlated variables $(r \geq 0.7)$. Depending on the response variables, we fitted models with a different structure. Poisson models were used for non-overdispersed count data, "quasi-Poisson" models were used for responses with an overdispersion lower than 15, negative binomial models were used in cases of overdispersion higher than 15, and binomial models were used for presence/absence response data (Tagliaferro \& Pascual, 2017). The best fitting models were chosen based on the lowest corrected Akaike's Information Criterion (AICc) value. Quasi-likelihood methods for small sample sizes (QAICc) were used with overdispersed data (Burnham \& Anderson, 2002). Note that we also ran GLMs for Chironomidae density, and its subfamilies' density and presence-absence. Dispersion tests, negative binomial models, multiple models and multi-model inference were carried out using "AER", "MASS", "glmulti" and "MuMIn" packages, respectively, in R Software (version 3.6.3, R Development Core Team, 2020).

\section{RESULTS}

Community structure and diversity distribution among stream site types: We collected a total of 90078 specimens belonging to 82 taxa and 15 macroinvertebrate orders from the 51 sampled sites (including rare taxa). Of these, 34 taxa belonged to Diptera (10 of which were from the family Chironomidae), 13 to Trichoptera, 11 to Coleoptera, 5 to Lepidoptera, 4 to Rhynchobdellida, 3 to Haplotaxida,
2 to Hemiptera, and 1 to Lumbriculida, Tricladida, Gordioidea, Hydracarina, Basommatophora, Podocopida, Amphipoda, Veneroida, Plecoptera, and Ephemeroptera. Removing rare taxa (see data analysis section) left us with 89767 specimens and 40 taxa, representing $99.7 \%$ of total abundance and $48.8 \%$ of total richness, respectively.

Kryal (K1 and K2) and mixed (M) site types had an important proportion of rare taxa (singletons and doubletons) (K1 $=9, \mathrm{~K} 2=13$ and $\mathrm{M}=19$, Fig. 2). These accounted for 42.9, 35.1 and $26.4 \%$ of all the taxa collected in those three site types, respectively. In contrast, rhithral and krenal stream site types, which were dominated by non-rare taxa, contributed to more than $80 \%$ of the total number of collected individuals (Fig. 2). Rarity in distribution revealed that the site type with the highest proportion of taxa found in a single locality were K2 sites, with 22 taxa of a total of 41 (54\%, Fig. 3). The other site types had lower proportions of taxa in single localities, ranging from $31 \%$ in rhithral sites to $37 \%$ in $\mathrm{M}$ sites (Fig. 3). In terms of uniqueness per site type, $\mathrm{M}$ and rhithral sites had the highest number of taxa present in only these types of sites ( 8 taxa each). In contrast, K1 and K2 sites harbored only two taxa unique to these types of sites (Table 1, Supp. Table S3). Commonness (i.e., shared species among all site types) was $15.9 \%$, meaning that 13 out 82 taxa were present at all types of sites (Table 1, Supp. Table S3).

Rhithral sites harbored the highest abundance of macroinvertebrates, whereas $M$ and $\mathrm{K} 1$ sites had the lowest numbers of individuals (Table 2). Mean richness was highest in the $\mathrm{M}$ sites and lowest in K1 sites (Table 1 \& 2). Rarefied richness (subsample of 44 individuals) showed that K2 sites were the richest (7.05) and $\mathrm{K} 1$ sites, the poorest (4.05, Table 2.). We found similar patterns for Shannon-Wiener (H) and true diversity (exponential Shannon) (Table 2, Fig. 4a).

Beta diversity (using Sorensen and BrayCurtis similarity indices) varied across site types, with kryal sites (K1 and K2) presenting the highest values for Sorensen ( 0.52 and 0.45 , 
A
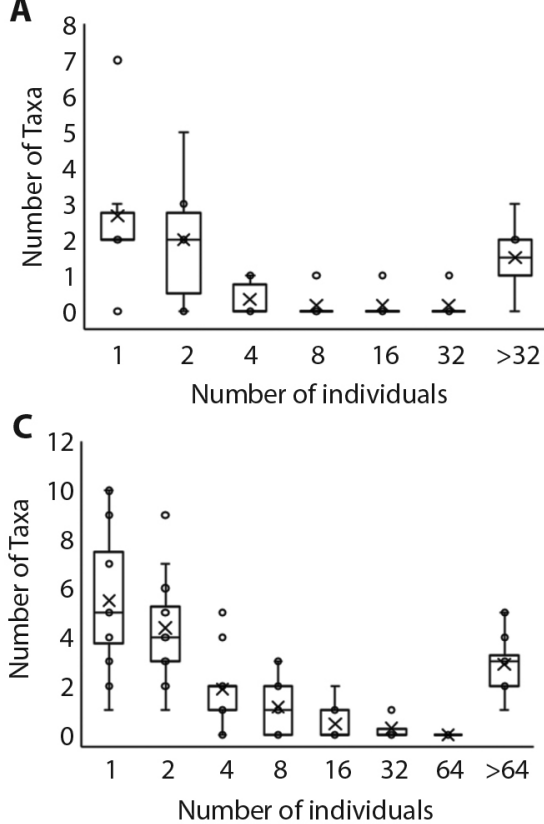

E

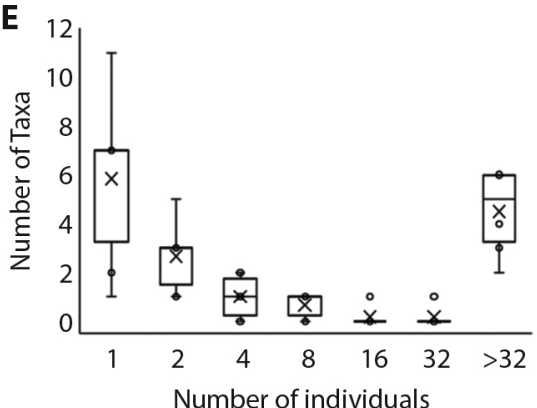

B

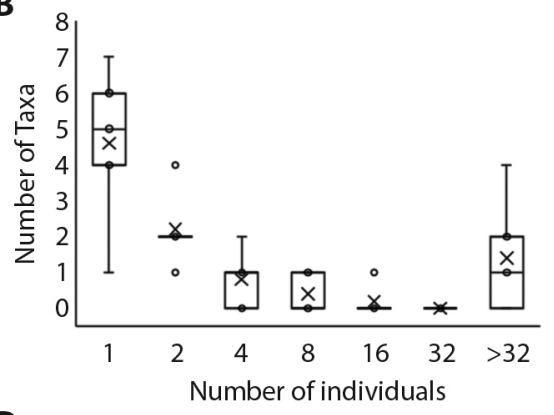

D

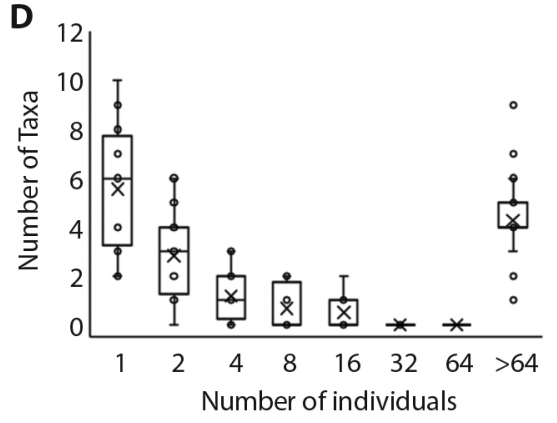

Fig. 2. Whisker plots of the number of taxa and the number of individuals found at (a) Kryal 1; (b) Kryal 2; (c) Mixed; (d) Rhithral and (e) Krenal sites. With mean, median and max-min values. Based on abundance data.

respectively) and $\mathrm{K} 2$ and rhithral, for BrayCurtis (0.74 and 0.70, respectively, Fig. 4b). On the other hand, the nestedness component of the Sorensen index differed among site types (ANOVA, $\mathrm{F}_{4,46}=6.05, p<0.001$ ), whereas the turnover component presented non-significant differences (ANOVA, $\mathrm{F}_{4,46}=1.6, p>0.05$ ). Post hoc HSD Tukey test showed that K1 sites differed from all the other site types in the nestedness component, but differed only from $\mathrm{M}$ sites in the overall component (Table 2, Fig. 4c).
Community composition patterns: Our analyses of similarity (ANOSIM) revealed significant differences between communities of the five types of sites $(\mathrm{R}=0.283, \mathrm{p}<0.01$, average dissimilarity $67.9 \%$ ). SIMPER analysis showed that Orthocladiinae (Chironomidae, Diptera), Hyalella sp. (Hyallelidae, Amphipoda) and Andesiops sp. (Baetidae, Ephemeroptera) contributed the most to this dissimilarity ( $>45 \%$ of cumulative contribution). K1 sites differed significantly from all the other site types (ANOSIM: $\mathrm{R}>0.6, \mathrm{p}<0.05$, average 

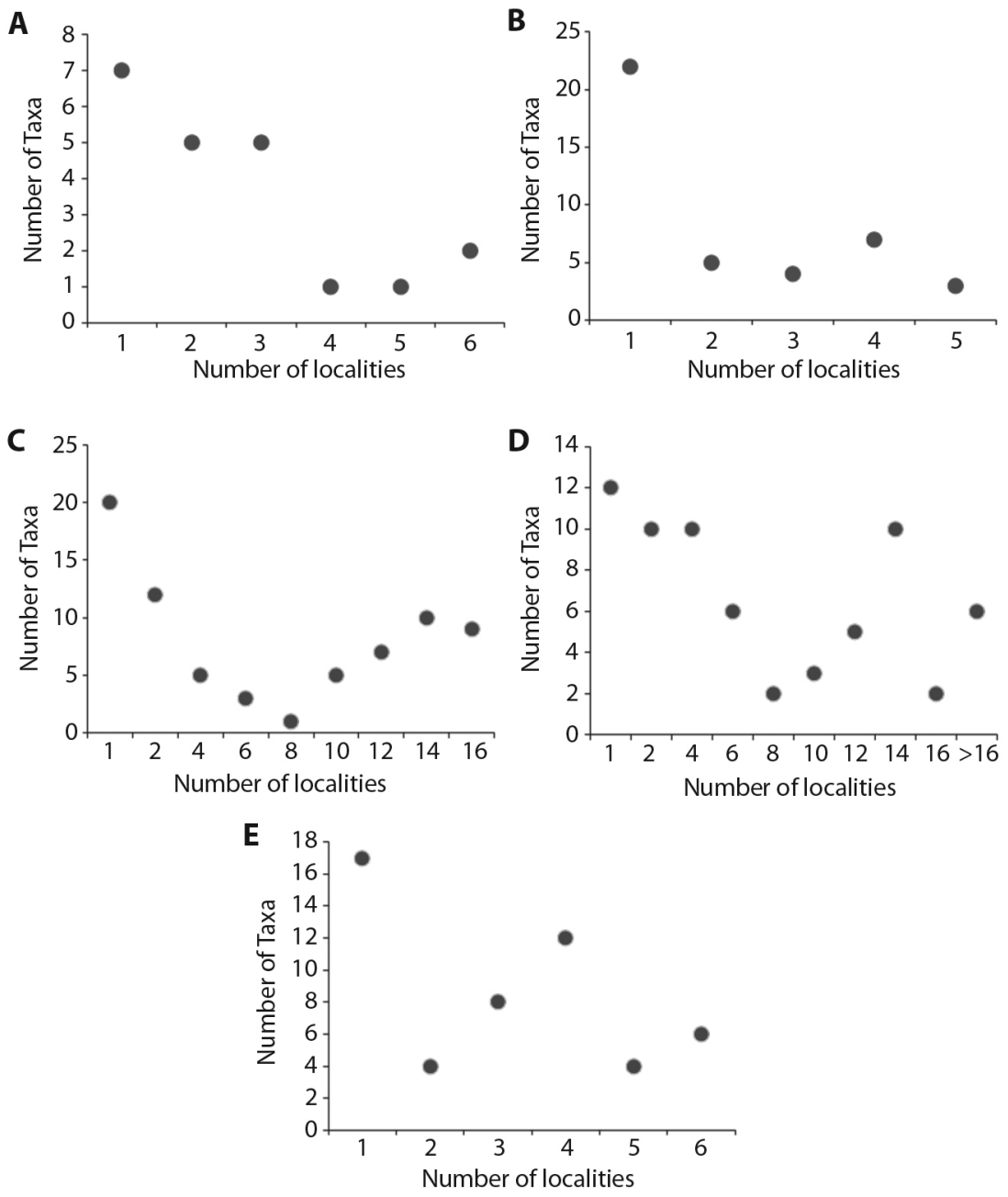

Fig. 3. Scatter plots of the number of taxa and the number of localities where the taxa were found at (a) Kryal 1; (b) Kryal 2; (c) Mixed; (d) Rhithral and (e) Krenal sites. Based on presence-absence data.

dissimilarity of $84.3 \%$ ), with Podonominae Type 1, Type 3 (Chironomidae, Diptera) and Orthocladiinae as the major contributors to those differences (Table 3). Hyalella sp. and Andesiops sp. were completely absent from K1 sites. Finally, K2 sites differed significantly from krenal sites (ANOSIM: $\mathrm{R}=0.55, \mathrm{p}<0.05$, average dissimilarity of $71.9 \%$ ), with Hyalella sp., Orthocladiinae and Neoelmis sp. (Elmidae, Coleoptera) as the major contributors to those differences, and Hyalella sp. presenting low densities (0.002 Ind $\left.\mathrm{m}^{-2}\right)$ in $\mathrm{K} 2$ sites (Table 3$)$.
Environmental gradients and driving factors: In our RDA, the first two canonical axes explained $60.2 \%$ of the variance in the macroinvertebrate-environment interaction (axis 1: $39.82 \%$ and axis 2: $20.36 \%$ ). Axis 1 was significantly defined by water temperature, CPOM, slope and turbidity, while axis 2 by current velocity, chlorophyll $a$ and stream width. The eigenvalues of axis 1 and 2 were 0.09 and 0.05 , respectively. Based on environmental vector lengths: water depth, turbidity, water temperature, current velocity and CPOM 


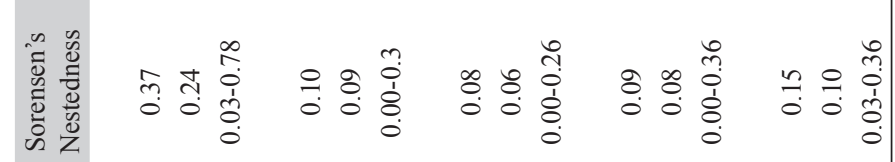

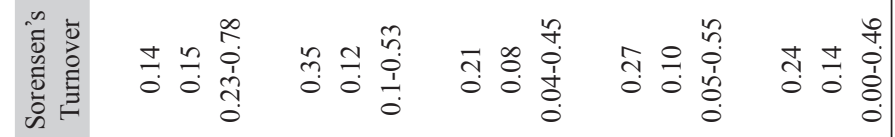

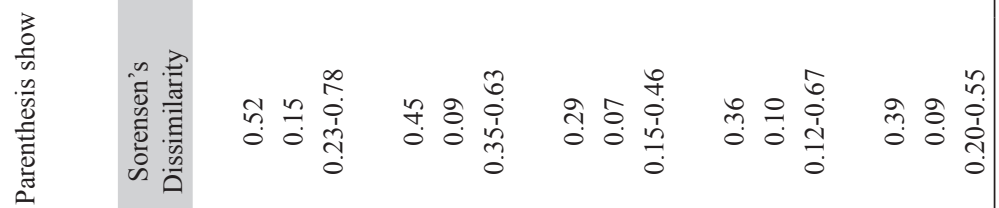

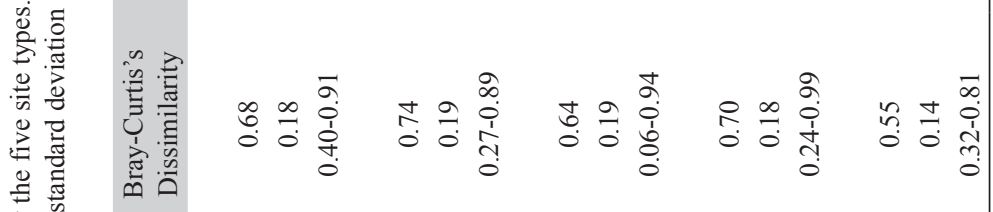

$$
\begin{aligned}
& \text { के } \\
& \text { 案邻 }
\end{aligned}
$$

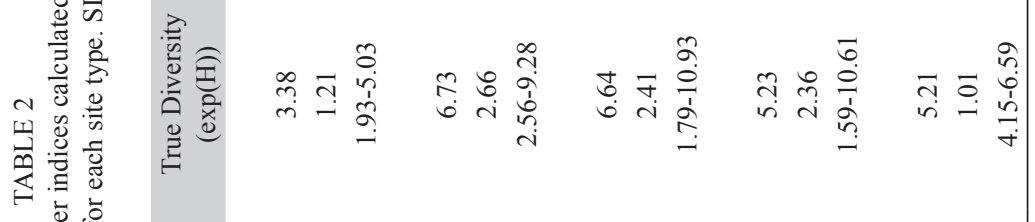

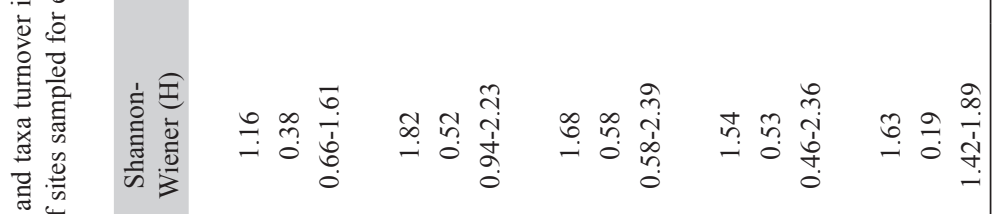

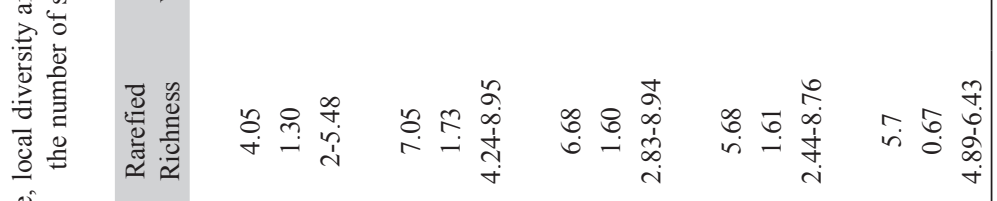

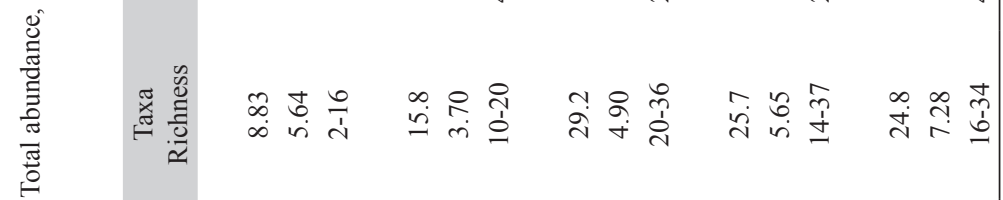

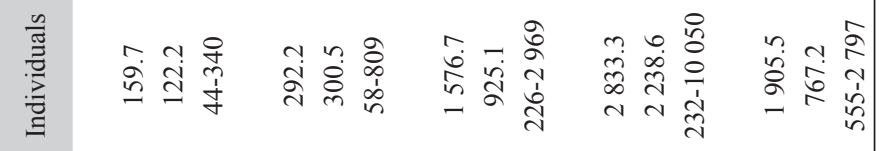

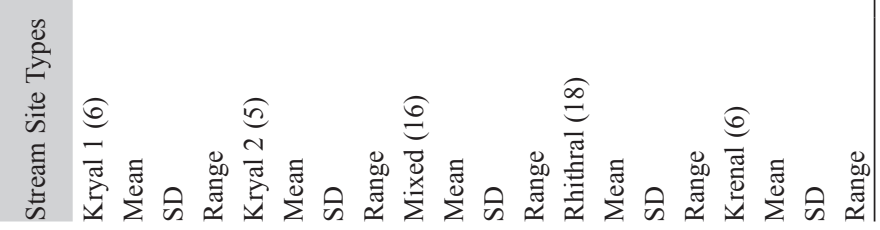



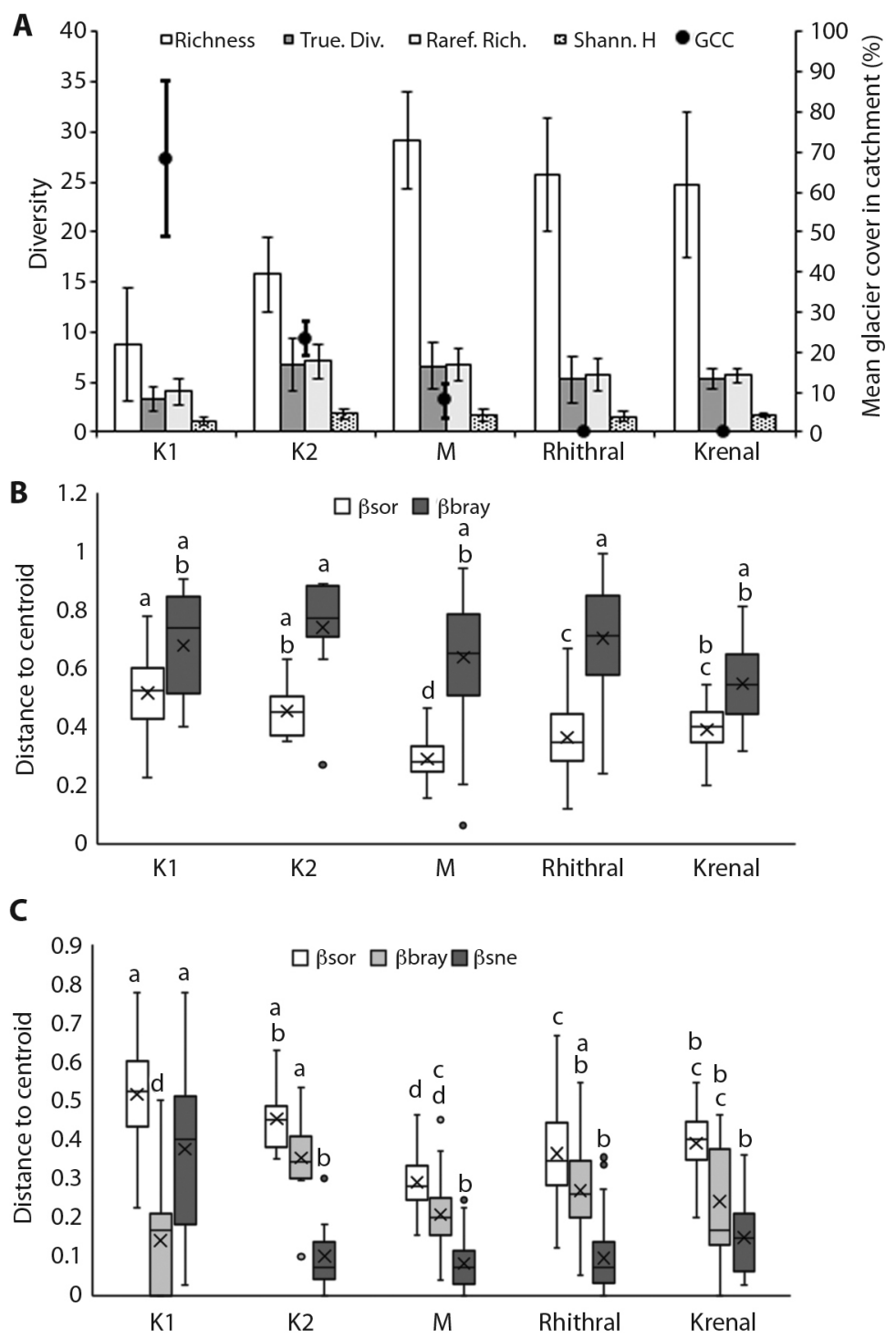

Fig. 4. Bar and Whisker plots of the measures of diversity. a) Mean Richness ( $\alpha$ diversity), True diversity (True Div.), Rarefied richness (Raref. Rich.), Shannon Index (Shannon H) and Glacier cover in catchment (GCC) per site type; b) Beta Sorensen ( $\beta$ sor) and Beta Bray-Curtis ( $\beta$ bray) with mean, median and max-min values and c) Beta Sorensen's overall ( $\beta$ sor), Beta Sorensen's turnover ( $\beta$ sim) and c) Beta Sorensen's nestedness ( $\beta$ sne) with mean, median and max-min values, different lowercase letters denote significant differences by Tukey's HSD tests between site types at $p<0.05$.

were the most important environmental factors (Fig. 5a). K1 sites were associated with higher values of GCC and turbidity and higher densities of Podonominae type 1, 3 and 4 (Fig. $5 \mathrm{~b})$. Water temperature, amount of CPOM and densities of Andesiops sp., Anomalocosmoecus sp. and Hyalella sp. were negatively associated with Kryal sites. Hyalella sp. and Ostracoda presented an association with higher $\mathrm{pH}$ and Pfankuch stability, whereas Orthocladinae was associated with higher current velocity and chlorophyll $a$ concentration.

GLMs showed that the main variables influencing macroinvertebrate richness were 
TABLE 3

SIMPER and ANOSIM results for macroinvertebrate community composition between the pooled group and the five study site types. Only the three taxa that contributed the most $(>10 \%)$ to the dissimilarity are shown

\begin{tabular}{|c|c|c|c|c|c|c|}
\hline \multirow[b]{2}{*}{ Sites } & \multicolumn{4}{|c|}{ SIMPER } & \multicolumn{2}{|c|}{ ANOSIM } \\
\hline & $\begin{array}{l}\text { Most discriminating } \\
\text { taxa }\end{array}$ & $\begin{array}{c}\text { Contribution } \\
(\%)\end{array}$ & $\begin{array}{l}\text { Cumulative } \\
\text { percentage }\end{array}$ & $\begin{array}{c}\text { Overall Average } \\
\text { Dissimilarity }\end{array}$ & $R$ & $p$ \\
\hline \multirow[t]{3}{*}{ K1 vs. K2 } & Podonominae Type 1 & 19.8 & 19.8 & & & \\
\hline & Podonominae Type 3 & 16.4 & 36.3 & 82.6 & 0.627 & 0.042 \\
\hline & Orthocladiinae & 12.5 & 48.7 & & & \\
\hline \multirow[t]{3}{*}{ K1 vs. M } & Podonominae Type 1 & 20.4 & 20.4 & & & \\
\hline & Orthocladiinae & 16.9 & 37.3 & 83 & 0.769 & 0.001 \\
\hline & Podonominae Type 3 & 16.4 & 53.7 & & & \\
\hline \multirow[t]{3}{*}{ K1 vs. Rhithral } & Podonominae Type 1 & 20.4 & 20.4 & & & \\
\hline & Podonominae Type 3 & 16.3 & 36.7 & 84.7 & 0.675 & 0.002 \\
\hline & Orthocladinae & 15.7 & 52.4 & & & \\
\hline \multirow[t]{3}{*}{ K1 vs. Krenal } & Hyalella sp. & 20.6 & 20.6 & & & \\
\hline & Podonominae Type 1 & 19.9 & 40.5 & 87 & 0.848 & 0.027 \\
\hline & Podonominae Type 3 & 15.9 & 56.5 & & & \\
\hline \multirow[t]{3}{*}{ K2 vs. M } & Orthocladiinae & 23.2 & 23.2 & & & \\
\hline & Neoelmis_sp. & 15.4 & 38.6 & 62.9 & 0.254 & 0.47 \\
\hline & Andesiops sp. & 10.5 & 49.1 & & & \\
\hline \multirow[t]{3}{*}{ K2 vs. Rhithral } & Orthocladiinae & 19.9 & 19.9 & & & \\
\hline & Neoelmis_sp. & 13.9 & 33.9 & 69.7 & 0.241 & 0.71 \\
\hline & Hyalella sp. & 13.4 & 47.3 & & & \\
\hline \multirow[t]{3}{*}{ K2 vs. Krenal } & Hyalella sp. & 24.7 & 24.7 & & & \\
\hline & Orthocladiinae & 14.6 & 39.3 & 71.9 & 0.547 & 0.02 \\
\hline & Neoelmis_sp. & 13.4 & 52.7 & & & \\
\hline \multirow[t]{3}{*}{ M vs. Rhithral } & Orthocladinae & 24.3 & 24.3 & & & \\
\hline & Andesiops sp. & 16 & 40.3 & 59.9 & 0.0503 & 1 \\
\hline & Hyalella sp. & 15.6 & 55.9 & & & \\
\hline \multirow[t]{3}{*}{ M vs. Krenal } & Hyalella sp. & 27 & 27 & & & \\
\hline & Orthocladiinae & 21.8 & 48.8 & 59.8 & 0.227 & 0.286 \\
\hline & Andesiops sp. & 13.1 & 61.9 & & & \\
\hline \multirow[t]{3}{*}{ Rhithral vs. Krenal } & Hyalella sp. & 24.5 & 24.4 & & & \\
\hline & Orthocladiinae & 21.3 & 45.8 & 56.7 & -0.098 & 1 \\
\hline & Andesiops sp. & 15 & 60.8 & & & \\
\hline
\end{tabular}

CPOM, current velocity (both with a positive relationship), the Pfankuch index and GCC (negatively related) (Table 4). Turbidity and GCC were the best variables to explain macroinvertebrate density with a negative relationship (Table 4). In the case of chironomids density and presence/absence, GCC appeared in most of the best-fitted models. The increase in GCC was related to high densities of Orthocladiinae, Diamesinae, Tanypodinae and Chironominae, and to the presence/absence of
Orthocladiinae and Tanypodinae. Water temperature had a negative effect on the densities of Podonominae, Diamesinae, Tanypodinae and Chironominae (Table 4).

\section{DISCUSSION}

Previous studies from the Antisana area have focused on longitudinal, spatial and temporal patterns of taxa composition and functional diversity, on community and 


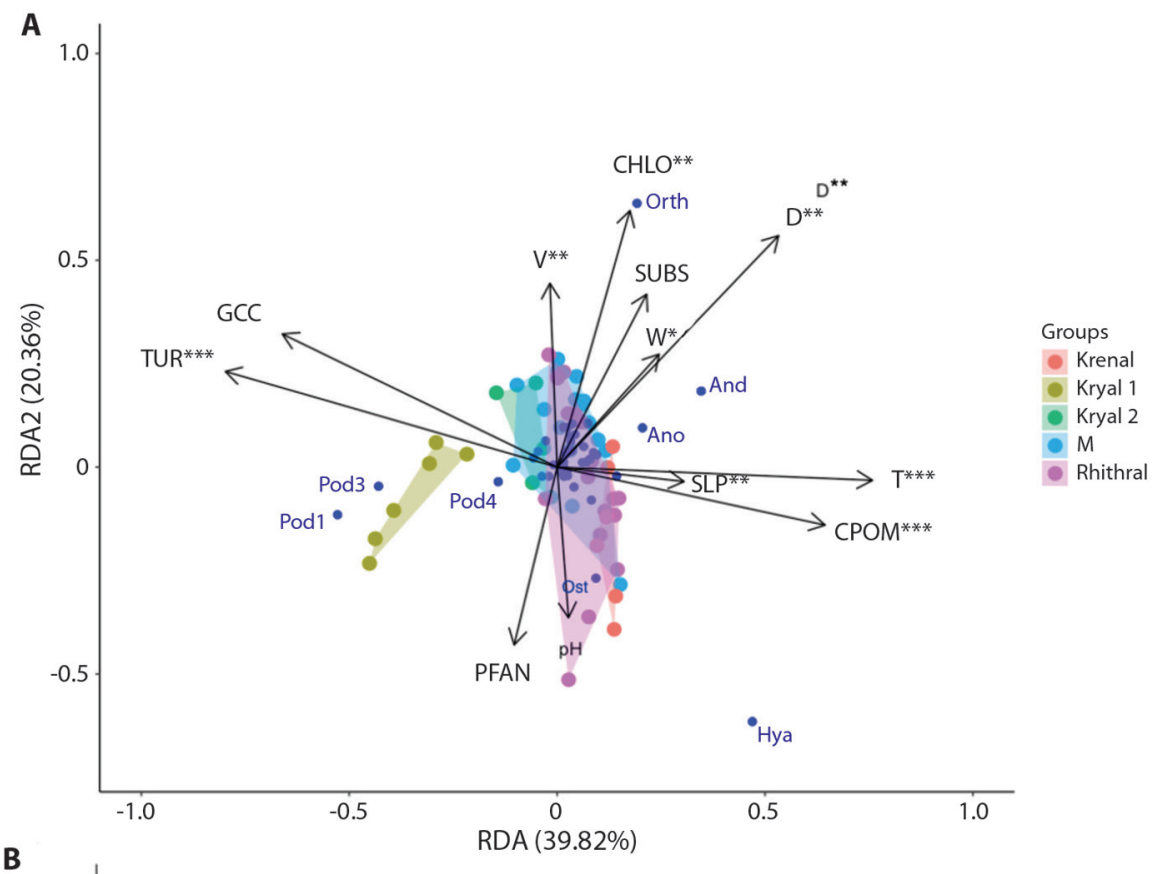

B

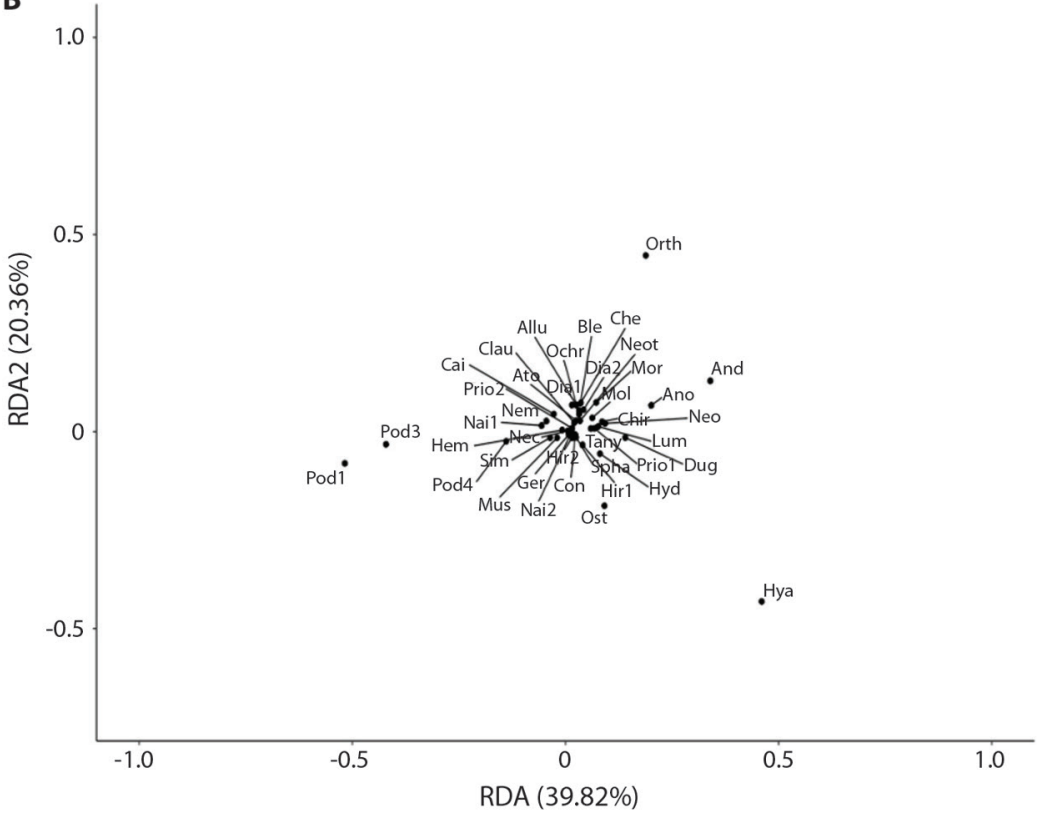

Fig. 5. Redundancy Analysis (RDA) of the biotic and abiotic variables and the benthic invertebrate communities sampled in 51 study sites, grouped by a) stream site types and b) macroinvertebrate assemblages where each point represents the benthic invertebrate assemblage of 5 pooled Surber samples from each of the 51 study sites. Macroinvertebrate densities (Ind $\left.\mathrm{m}^{-2}\right)$ were Hellinger transformed and environmental variables were $\log (\mathrm{x}+1)$ transformed. Significant codes: $* * * P<0.001$; ** $P<0.01$ and $* P<0.05$ obtained by 999 permutations. And: Andesiops sp., Ble: Blepharicera sp., Ger: Geranomyia sp., Hem: Hemerodromia sp., Hir1 \&2: Hirudinea type 1\&2, Hya: Hyalella sp., Mor: Mortoniella sp., Nec: Nectopsyche sp., Orth: Orthocladiinae, Ost: Ostracoda, Pod1, 3 \& 4: Podonominae type 1, 3 \& 4, Spha: Sphaeriidae. TUR: Turbidity, GCC: Glacier cover per catchment, PFAN: Pfankuch Index, V: Current velocity, CHLO: Chlorophyll $a$, SUBS: Substrate Types, W: Stream width, D: Stream depth, SLP: Stream slope, CPOM: Coarse particulate organic matter and T: Water temperature. 


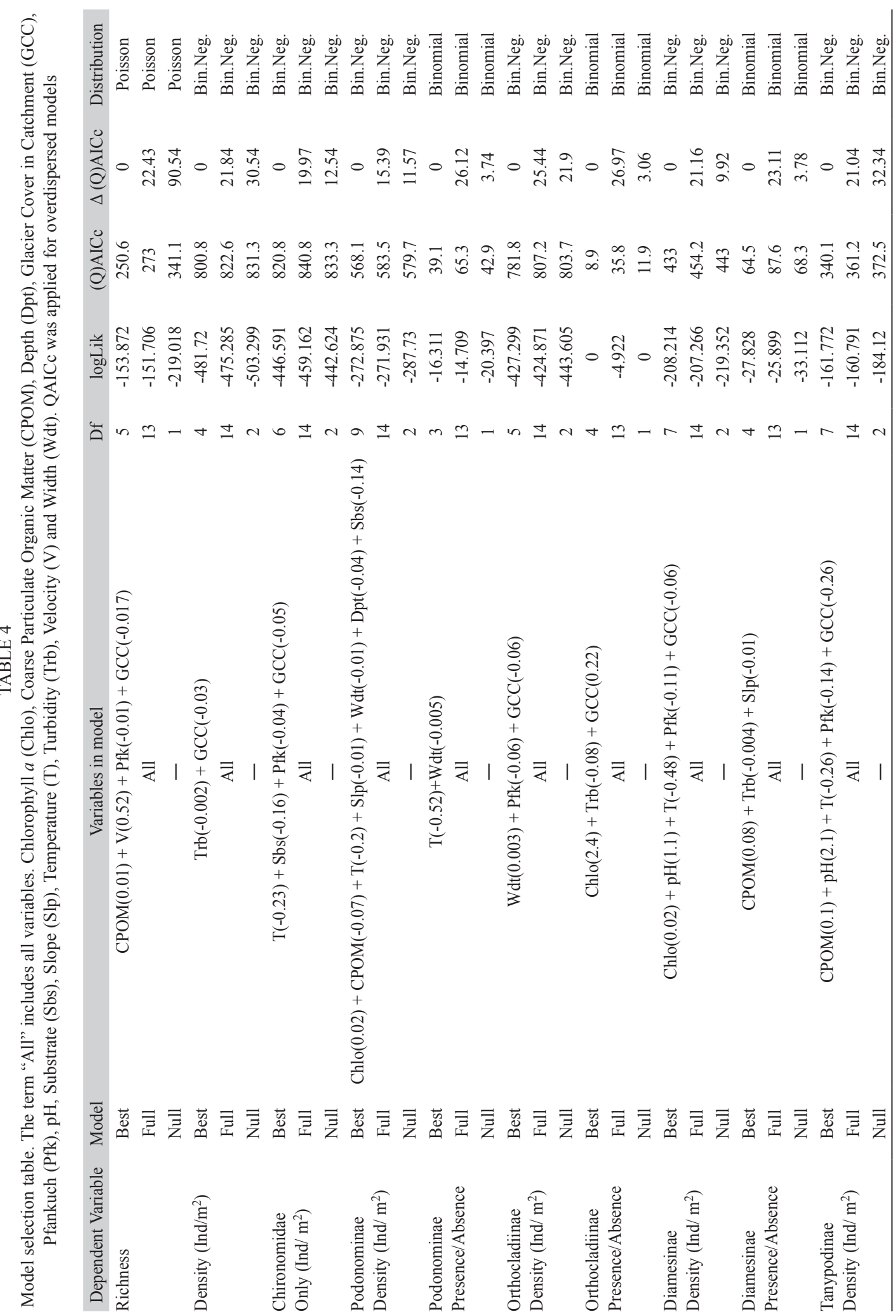




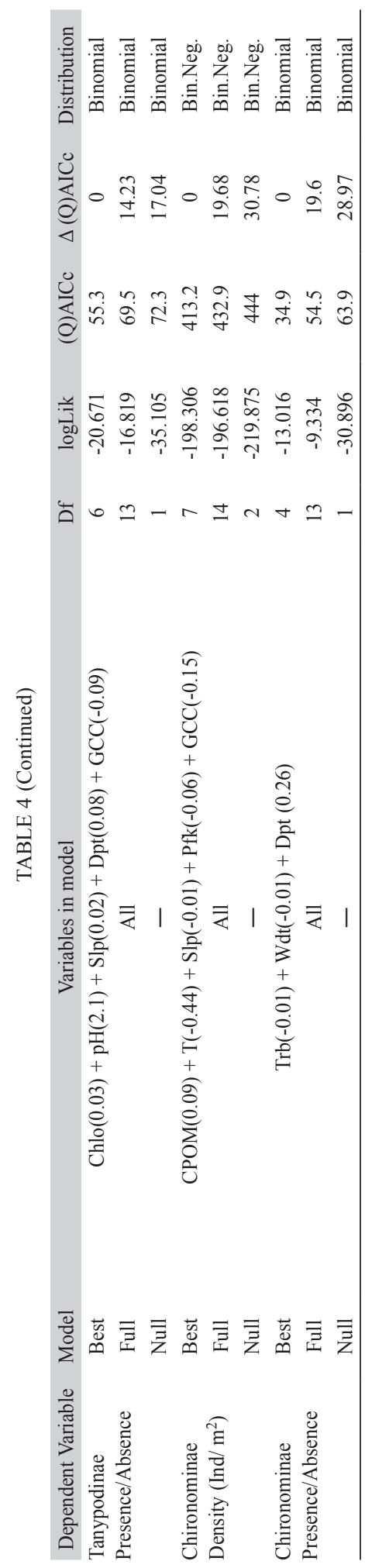

metacommunity structure and on experimental ecological responses to environmental drivers, physical forces, ecosystem functioning and climate change induced reduction in water flow (Jacobsen et al., 2010; Kuhn et al., 2011; Fugère et al., 2012; Cauvy-Fraunié et al., 2014b; 2015; 2016; Tiegs et al., 2019; Crespo-Pérez et al., 2020). The novelty of the present study lies on the study of $\alpha$ and $\beta$ diversity (local diversity and taxa turnover, respectively), on the subclassification of stream site types (i.e., kryal 1, kryal 2, mixed, krenal and rhithral) and on the analysis of rare and common taxa between these site types. Our a priori grouping of sites was confirmed to be acceptable according to the results obtained in the ANOSIM and RDA analysis, and supports the hypothesis that distinct benthic macroinvertebrate assemblages would inhabit streams of different origins (Brown, Milner \& Hannah, 2006). Our study also revealed how diversity patterns ( $\alpha$ and $\beta$ ) varied along environmental gradients (i.e., GCC, temperature, turbidity, etc.) and among different site types at the catchment scale.

Commonness, rarity and diversity gradients: Understanding how the distribution of rare and common taxa contributes to the emergence of biodiversity patterns is a key concern in conservation biology (Lennon et al., 2004; Pearman \& Weber, 2007). In this study, we found differences in the composition of aquatic communities between sites with different water sources. We found unique taxa in all the site types (i.e., taxa that were present only in a particular site type), with rhithral and $\mathrm{M}$ sites having 12 and 9 singletons, respectively, which corresponded to 13 and $10 \%$ of the total richness found in the study (Fig. 2). In kryal sites $(2,8$ and 9$)$ we found two unique taxa, Dytiscidae and Staphylinidae type 1 (Coleoptera), that were not found in any of the other site types. This could represent only chance encounters, or could reveal recent colonization of these harsh environments by these predatory taxa. This result could also be related to the reduced number of K1, K2 and krenal sites, compared to mixed and rhithral sites. More data, especially 
from kryal and krenal sites, are needed to confirm this finding. However, some Staphylinidae have indeed been found to be adapted for life in subaquatic conditions near the stream channel (Domínguez \& Fernández, 2009; Lancaster \& Downes, 2013). Podonominae type 4 (Diptera) were present in all the sites that were influenced by glacial melt water (K1, K2 and M), but not in rhithral or krenal sites, which could mean that this chironomid is highly adapted to conditions of glacier-fed streams (CauvyFraunié et al., 2015). On the other hand, there were 13 taxa that were present in all five stream site types [e.g., Atopsyche sp. (Trichoptera), Cailloma sp. (Trichoptera), Simulium sp. (Diptera), Hemerodromia sp. (Diptera), Molophilus sp. (Diptera), Podonominae type 3 (Diptera), etc.], but more analyses (e.g., genetic barcodes) are necessary to determine if each taxon corresponds only to one or to several species. If the former were true this would mean that these species have plastic habitat requirements and/ or high dispersal capacity (all of them have an adult flying stage), and adaptations (e.g., morphological and physiological) for life under all these high altitude conditions. As observed by Alther et al. (2019) in the Swiss Alps, high altitude glacierised catchments harbor a surplus of generalist species, with a few rare species, compared to other ecosystems.

As found in previous studies (Jacobsen et al., 2012; Cauvy-Fraunié et al., 2014a), our results revealed a peak in richness at intermediate levels of glacier influence. As stated by these authors, this could be explained by the intermediate disturbance hypothesis (Connell, 1978). Indeed, intermediate disturbance at mixed sites could favor the presence of disturbance tolerant taxa, while reducing the abundance of competitive, disturbance averse taxa (Crespo-Pérez et al., 2020). Another possible explanation to the higher diversity of mixed sites, could be that these sites receive more individual colonists, both from upstream reaches (e.g., from kryal and rhithral sites) and from lateral movements between branches (Crespo-Pérez et al., 2020, Brown and Swan, 2010). Our results based on Sorensen's measures of dissimilarity showed that nestedness (sites with lower richness are subsets of sites with higher richness) (Ulrich $\&$ Gotelli, 2007) better explains the difference between our communities. Sites with stronger glacier influence (K1) differed from all the other types of sites according to RDA, ANOSIM and Tukey's HSD post hoc tests (Fig. 4c), which could reflect a non-random process of species loss across these site types that promotes these disaggregated assemblages (Gaston \& Blackburn, 2000). As expected, and in accordance to previous studies, Sorensen's overall dissimilarity increased with increasing glacial influence (which is significantly correlated with altitude, Supp. Table S2) (Finn et al, 2013; Castro et al., 2019). This process could be explained by an increment of environmental heterogeneity between sites, which in turn, increases regional diversity (Cauvy-Fraunié et al., 2015; Crespo-Pérez et al., 2020).

Community composition, environmental characteristics and driving factors: Hyalella sp. (Amphipoda) and Andesiops sp. (Ephemeroptera) were distributed in all our site types except for the K1 sites. Anomalocosmoecus sp. (Trichoptera) was present in all sites but not in all kryal sites. Hyalellidae amphipods have been found to present some degree of trophic plasticity (Wantzen \& Wagner, 2006) and successful adaptation to a variety of environmental conditions (Acosta \& Prat, 2011), but they were found to have high mortality rates when transplanted to high altitude streams (c.a. 4500 m.a.s.l.) (Madsen et al., 2015). On the other hand, Andesiops ephemeropterans, are commonly found and are relatively abundant in hig altitude ecosystems of Ecuador, and as proposed by Finn et al. (2016), this genus presents recent population growth, in evolutionary terms, at the upstream catchment scale. These populations of Andesiops sp. and Anomalocosmoecus sp. proved to be very sensitive to temperature in transfer experiments, with high mortality rates above 4200 m.a.s.l. (Madsen et al., 2015). Therefore, these three taxa seem to be competitive and dominant under relatively benign conditions, but are excluded 
by the extreme environmental conditions of kryal sites.

Macroinvertebrate communities seemed to be affected primarily by environmental factors such as turbidity, water temperature, CPOM, current velocity and chlorophyll $a$. Certain macroinvertebrate taxa (e.g., Diamesinae, Baetidae, Leptophlebiidae and Podonominae) have been shown by previous studies to have greater tolerance to glacial influence than other less tolerant taxa (Milner et al., 2001b, Ilg \& Castella, 2006; Milner et al., 2009). GCC influences the stream thermal regime (Hood \& Berner, 2009), with temperature increasing farther downstream as glacial influence dampens; this temperature gradient is expected to decline with warming climates and glacial recession (Slemmons, Saros \& Simon, 2013). Channel stability and water temperature are key physicochemical drivers influencing longitudinal trends in macroinvertebrate assemblages along proglacial rivers (Milner et al., 2001a). In our study, channel stability seemed to be an antagonistic force to current velocity and enhanced the density of certain taxa like Ostracoda and Hyalella sp. Several studies have found current velocity to be an important driver of stream macroinvertebrate assemblages (e.g., Hieber et al., 2005; Skoulikidis, Karaouzas \& Gritzalis, 2009; Cauvy-Fraunié et al., 2014a; b), and in our case, positively affected the density of certain rheophilic macroinvertebrates such as Blepharicera sp. (Diptera) (Fig. 5b).

Macroinvertebrate richness was positively influenced by CPOM and stream current velocity. CPOM has been previously linked to the number of taxa occurring in headwater streams (Fenoglio et al., 2005; Straka, Syrovátka \& Helešic, 2012); although, a previous study limited to nine glacier-fed sites in the same region, did not find a relationship between the fauna and CPOM levels (Kuhn et al., 2011). On the other hand, we found that macroinvertebrate density was negatively related to turbidity and GCC, with both environmental factors being strongly correlated with water temperature and conductivity (Table 4).
According to previous studies (e.g., Jacobsen et al., 2010; 2014; Kuhn et al., 2011) chironomids are numerically dominant in our study region. In temperate European streams, as one gets closer to the glacier, Diamesa sp. (Diamesinae, Chironomidae) becomes the only genera present (Milner et al., 2001a; Clitherow, Carrivick \& Brown, 2013); a pattern observed with Podonominae in Ecuadorian tropical glacierised catchments (Jacobsen et al., 2010). More specifically, we found that Podonominae type 1 and 3 were abundant at kryal sites, but Podonominae type 4 was the only taxon found exclusively at the upper-most sites. The latter taxon probably belongs to the genus Parochlus, but further taxonomic identification is mandatory in order to confirm its endemic status in these Ecuadorian Andes streams. Diamesa species found in a harsh glacier-fed stream in the Central Austrian Alps were found to have an omnivorous diet rich in detritus and diatoms (Clitherow, Carrivick \& Brown, 2013). Likewise, according to our GLM analysis, the relative abundance of the subfamily Podonominae was positively influenced by CPOM quantity and chlorophyll $a$ concentration (but note that CPOM and chlorophyll $a$ were negatively related to GCC), and their presence was negatively influenced by water temperature and stream width (Table 4, Supp. Table S2). All this suggests that the ecological niche necessary for the presence and abundance of certain chironomid species in harsh glacier conditions are similar for temperate and tropical glacier-fed streams.

In conclusion, given the relatively little knowledge about mountaintop invertebrates, and the increased threat posed by climate change, more research and monitoring is urgently needed to predict and adapt to the effects of taxa extirpation on ecosystem integrity and functioning (Muhlfeld et al., 2011). There is an urgent need to expand the spatial range of tropical glacierised catchment studies, to apply state-of-the-art research techniques (e.g., next generation sequencing, stable isotope analyses, species distribution modeling) and to expand research topics (e.g., functional diversity, genetic diversity) in glacier-fed 
catchments in order to discover new endemic species, unveil patterns of genetic structuring and key functional and ecological roles in these highly fragile and understudied tropical ecosystems. Finally, as proposed by Jacobsen et al. (2012), the potential threats to biodiversity suggest that strategic conservation should, from now on, take a holistic approach that includes both invertebrate and vertebrate aquatic species. Detailed analyses of benthic communities and the development of databases are key for conservation strategies. In general, water management municipalities and/or enterprises tend to focus on mountain streams' flows, but this study highlights that water managers should also consider water quality and stream site types for more sustainable management of these important ecosystems.

Ethical statement: authors declare that they all agree with this publication and made significant contributions; that there is no conflict of interest of any kind; and that we followed all pertinent ethical and legal procedures and requirements. All financial sources are fully and clearly stated in the acknowledgements section. A signed document has been filed in the journal archives.

\section{ACKNOWLEDGMENTS}

We thank everyone who assisted us with field and laboratory work, especially to the members of the Limnology Laboratory of PUCE, who assisted in the sorting and identification of aquatic macroinvertebrates. Funding by Ecofondo (grant no. 034-ECO8-inv1) and by a WWF-Novozymes (grant 2008) is greatly appreciated. A special thanks to Kirstynn Joseph for reviewing the English writing. We thank Mr. Jose Delgado and Antisana Ecological Reserve for granting us access to the study sites. Specimens were collected under permit $\mathrm{N}^{\circ}$ 008-09 IC-FAU-DNB/MA from Ministerio de Ambiente of Ecuador.

\section{RESUMEN}

Patrones de diversidad de macroinvertebrados acuáticos en una cuenca tropical altoandina. Introducción: Las cuencas glaciares son entornos remotos y hostiles, en los que los arroyos de diferentes fuentes de agua (p.ej., deshielo de glaciares, lluvia/deshielo, agua subterránea) convergen, creando un mosaico complejo de tramos con diferentes niveles de influencia glacial y condiciones ambientales. Esta heterogeneidad ambiental influye, a su vez, en el ensamblaje y composición de las comunidades acuáticas y produce complejos patrones de diversidad a la escala de la cuenca. Objetivos: En esta contribución, evaluamos la biodiversidad y composición de comunidades de macroinvertebrados acuáticos en 51 sitios de una cuenca glaciar en los Andes tropicales. Los objetivos de nuestro estudio fueron: (1) determinar la diversidad, la contribución de taxones raros y comunes y los patrones de distribución espacial de las comunidades de macroinvertebrados acuáticos en sitios con diferentes fuentes de agua, y (2) identificar qué variables ambientales influyen en la densidad y presencia de taxones de macroinvertebrados y, en particular, de las subfamilias de los omnipresentes quironómidos. Métodos: Agrupamos a nuestros sitios de estudio según su fuente de agua y su porcentaje de cobertura de glaciar en la cuenca (GCC). En cada sitio donde muestreamos macroinvertebrados acuáticos, medimos variables ambientales y evaluamos las diferencias entre comunidades y la influencia ambiental con análisis de ordenación y modelos lineales generalizados. Resultados: Los sitios kryal y mixtos tuvieron una proporción importante de taxones raros. La riqueza media fue más alta en los sitios mixtos y más baja en los sitios con mayor cobertura glaciar; mientras que los sitios con un porcentaje intermedio de cobertura glaciar tuvieron los valores más altos de diversidad $\alpha$ y $\beta$. Encontramos que 13 taxones $(15,9 \%)$ fueron comunes a todos los tipos de sitios de estudio. El análisis SIMPER mostró que Orthocladiinae, Hyalella sp. y Andesiops sp. contribuyeron más a la disimilitud entre tipos de sitios ( $>45 \%$ de la contribución acumulada). El RDA mostró que los sitios kryal estaban asociados con alta turbidez y densidad de podonómidos, y con baja temperatura, cantidad de CPOM y densidad de Anomalocosmoecus sp. y Andesiops sp. Orthocladinae se asoció con una alta velocidad de corriente y concentración de clorofila $a$, mientras que Hyalella sp. tuvo una relación positiva con $\mathrm{pH}$ más alto y estabilidad del lecho del río. Los modelos lineales generalizados mostraron que GCC fue la variable principal para explicar todas las métricas de fauna. La velocidad de corriente explicó la abundancia de macroinvertebrados, la temperatura del agua estuvo relacionada con la densidad de los quironómidos y la clorofila influenció la presencia-ausencia de Orthocladiinae. Conclusiones: Nuestros resultados sugieren que, al favorecer 
la presencia de taxones raros y la rotación de taxones, la influencia de los glaciares puede aumentar la biodiversidad en cuencas con influencia glaciar. En términos de conservación de la biodiversidad, este estudio confirma la necesidad urgente de incrementar el conocimiento de la biodiversidad en arroyos de la región altoandina, especialmente en cuencas glaciares altamente heterogéneas, para describir mejor los patrones de biodiversidad regional y la composición de las comunidades en estos ecosistemas altamente vulnerables. Análisis detallados de las comunidades bentónicas y el desarrollo de bases de datos son claves para diseñar estrategias de conservación. Los municipios y/o empresas administradoras de agua deben considerar la calidad del agua y los tipos de arroyos para una gestión más sostenible de estos importantes ecosistemas.

Palabras clave: macroinvertebrados acuáticos; cuencas glaciares; krenal; kryal; rareza, rhithral.

\section{REFERENCES}

Acosta, R., \& Prat, N. (2011). Trophic ecology of Hyalella sp. (Crustacea: Amphipoda) in a high Andes headwater river with Travertine Deposits. International Review of Hydrobiology 96, 274-285.

Alahuhta, J., Johnson, L.B., Olker, J., \& Heino, J. (2014). Species sorting determines variation in the community composition of common and rare macrophytes at various spatial extents. Ecological Complexity 20, 61-68.

Alther, R., Thompson, C., Lods-Crozet, B., \& Robinson, C.T. (2019). Macroinvertebrate diversity and rarity in non-glacial Alpine streams. Aquatic Sciences 81, 42.

Baselga, A., \& Orme, C.D.L. (2012). betapart: an R package for the study of beta diversity. Methods in Ecology and Evolution, 3(5), 808-812.

Borcard, D., Gillet, F., \& Legendre, P. (2018). Numerical ecology with $R$. Springer.

Brown, B.L., \& Swan, C.M. (2010). Dendritic network structure constraints metacommunity properties in riverine eco-systems. Journal of Animal Ecology 79, 571-580.

Brown, L.E., Hannah, D.M., \& Milner, A.M. (2003). Alpine stream habitat classification: An alternative approach incorporating the role of an alternative habitat classification: Stream approach incorporating alpine contributions of dynamic water source the role. Arctic, Antarctic, and Alpine Research 35, 313-322.

Brown, L.E., Milner, A.M., \& Hannah, D.M. (2006). Stability and persistence of alpine stream macroinvertebrate communities and the role of physicochemical habitat variables. Hydrobiologia 560, 159-173.
Burnham, K.P., \& Anderson, D.R. (2002). Model selection and multimodel inference: A practical informationtheoretic approach, Second ed. Springer-Verlag, New York.

Cao, Y., Larsen, D.P., \& Thorne R.S.-J. (2001). Rare species in multivariate analysis for bioassessment: some considerations. Journal of the North American Benthological Society 20, 144-153.

Castro, D.M., Callisto, M., Solar, R.R., Macedo, D.R., \& Fernandes, G.W. (2019). Beta diversity of aquatic invertebrates increases along an altitudinal gradient in a Neotropical mountain. Biotropica, 51(3), 399-411.

Cauvy-Fraunié, S., Andino, P., Espinosa, R., Calvez. R., Anthelme, F., Jacobsen, D., Dangles, O. (2014a) Glacial flood pulse effects on benthic fauna in equatorial high-Andean streams. Hydrological Processes 28(6), 3008-3017.

Cauvy-Fraunié, S., Espinosa, R., Andino, P., Dangles, O., \& Jacobsen, D. (2014b) Relationships between stream macroinvertebrate communities and new flood-based indices of glacial influence. Freshwater Biology 59, 1916-1925.

Cauvy-Fraunié, S., Espinosa, R., Andino, P., Jacobsen, D., \& Dangles, O. (2015). Invertebrate metacommunity structure and dynamics in an Andean glacial stream network facing climate change. PLOS ONE 10, 1-19.

Cauvy-Fraunié, S., Andino, P., Espinosa, R., Calvez, R., Jacobsen, D., \& Dangles, O. (2016). Ecological responses to experimental glacier-runoff reduction in alpine rivers. Nature Communications 7, 1-7.

Chapman, M., \& Underwood, A. (1999). Ecological patterns in multivariate assemblages: information and interpretation of negative values in ANOSIM tests. Marine Ecology Progress Series.

Chase, J.M. (2007). Drought mediates the importance of stochastic community assembly. Proceedings of the National Academy of Sciences 104, 17430-4.

Crespo-Pérez, V., Dangles, O., Ibarra, C., Espinosa, R., Andino, P., Jacobsen, D., \& Cauvy-Fraunié, S. (2020). Functional structure and diversity of invertebrate communities in a glacierised catchment of the tropical Andes. Freshwater Biology. DOI: 10.1111/ fwb.13504

Clitherow, L.R., Carrivick, J.L., \& Brown, L.E. (2013). Food web structure in a harsh glacier-fed river. PLoS ONE 8, e60899.

Connell, J.H. (1978). Diversity in Tropical Rain Forests and Coral Reefs. Science, New Series 199, 1302-1310.

Cucherousset, J., Santoul, F., Figuerola, J., \& Céréghino, R. (2008). How do biodiversity patterns of river animals emerge from the distributions of common and rare species? Biological Conservation 141, 2984-2992. 
Domínguez, E., \& Fernández, H.R. (2009). Macroinvertebrados bentónicos sudamericanos: sistemática y biología. Fundación Miguel Lillo.

Fenoglio, S., Bo, T., Agosta, P., \& Malacarne, G. (2005). Temporal and spatial patterns of coarse particulate organic matter and macroinvertebrate distribution in a low-order Apennine stream. Journal of Freshwater Ecology 20, 539-547.

Finn, S.D., Khamis, K., \& Milner, A.M. (2013). Loss of small glaciers will diminish beta diversity in Pyrenean streams at two levels of biological organization. Global Ecology and Biogeography 22, 40-51.

Finn, D.S., Encalada, A.C., \& Hampel, H. (2016). Genetic isolation among mountains but not between stream types in a tropical high-altitude mayfly. Freshwater Biology 61, 702-714.

Fugère, V., Andino, P., Espinosa, R., Anthelme, F., Jacobsen, D., \& Dangles, O. (2012). Testing the stressgradient hypothesis with aquatic detritivorous invertebrates: insights for biodiversity-ecosystem functioning research. The Journal of Animal Ecology 81, 1259-67.

Füreder, L. (1999). High alpine streams: cold habitats for insect larvae. In: Cold-Adapted Organisms. Ecology, Physiology, Enzymology and Molecular Biology. (Eds R. Morgesin \& F. Schinner), pp. 181-196. Springer-Verlag, Berlin.

Füreder, L. (2007). Life at the edge: Habitat condition and bottom fauna of alpine running waters. International Review of Hydrobiology 92, 491-513.

Gaston, K.J., \& Blackburn, T.M. (2000). Pattern and process in macroecology. Blackwell Science, Oxford.

Giller, P.S. \& Malmqvist, B. (1998). The biology of streams and rivers. Oxford University Press.

Heino, J. \& Soininen, J. (2010). Are common species sufficient in describing turnover in aquatic metacommunities along environmental and spatial gradients? Limnology and Oceanography 55, 2397-2402.

Hieber, M., Robinson, C.T., Uehlinger, U., \& Ward, J.V. (2005). A comparison of benthic macroinvertebrate assemblages among different types of alpine streams. Freshwater Biology 50, 2087-2100.

Hood, E., \& Berner, L. (2009). Effects of changing glacial coverage on the physical and biogeochemical properties of coastal streams in southeastern Alaska. Journal of Geophysical Research 114, G03001.

Ilg, C. \& Castella, E. (2006) Patterns of macroinvertebrate traits along three glacial stream continuums. Freshwater Biology 51, 840-853.

Jacobsen, D., Dangles, O., Andino, P., Espinosa, R., Hamerlík, L., \& Cadier, E. (2010). Longitudinal zonation of macroinvertebrates in an Ecuadorian glacier-fed stream: do tropical glacial systems fit the temperate model? Freshwater Biology 55, 1234-1248.

Jacobsen, D., \& Dangles, O. (2012). Environmental harshness and global richness patterns in glacier-fed streams. Global Ecology and Biogeography 21, 647-656.

Jacobsen, D., Milner, A.M., Brown, L.E., \& Dangles, O. (2012). Biodiversity under threat in glacier-fed river systems. Nature Climate Change 2, 1-4.

Jacobsen, D., Andino, P., Calvez, R., Cauvy-Fraunié, S., Espinosa, R., \& Dangles, O. (2014). Temporal variability in discharge and benthic macroinvertebrate assemblages in a tropical glacier-fed stream. Freshwater Science 33, 32-45.

Josefson, A.B. (2009). Additive partitioning of estuarine benthic macroinvertebrate diversity across multiple spatial scales. Marine Ecology Progress Series, 396, 283-292.

Jost, L. (2006). Entropy and diversity. Oikos, 113(2), 363-375.

Kuhn, J., Andino, P., Calvez, R., Espinosa, R., Hamerlik, L., Vie, S., ... Jacobsen, D. (2011). Spatial variability in macroinvertebrate assemblages along and among neighbouring equatorial glacier-fed streams. Freshwater Biology 56(11), 2226-2244. https://doi. org/10.1111/j.1365-2427.2011.02648.x

Kunin, W.E., \& Gaston, K.J. (1993). The biology of rarity: Patterns, causes and consequences. Trends in Ecology and Evolution 8, 298-301.

Lancaster, J. \& Downes, B.J. (2013). Aquatic entomology, First Edit. Oxford University Press.

Legendre, P. \& Legendre, L. (1998). Numerical Ecology, 2nd edn. Elsevier, Amsterdam.

Leibold, M.A., Holyoak, M., Mouquet, N., Amarasekare, P., Chase, J.M., Hoopes, M.F., ... Gonzalez, A. (2004). The metacommunity concept: a framework for multi-scale community ecology. Ecology Letters 7, 601-613.

Lencioni, V., Rossaro, B., \& Maiolini B., (2007). Alpine chironomid distribution: a mere question of altitude? In: Contributions to the Systematics and Ecology of Aquatic Diptera - A Tribute to Ole A. Sather. Andersen, T. (Ed.) The Caddis Press, Ohio (USA), pp. 165-180.

Lencioni, V. (2018). Glacial influence and stream macroinvertebrate biodiversity under climate change: Lessons from the Southern Alps. Science of the Total Environment 622, 563-575. 
Lennon, J.J., Koleff, P., Greenwood, J.J.D. \& Gaston, K.J. (2004). Contribution of rarity and commonness to patterns of species richness. Ecology Letters 7, 81-87.

Lepš, J. \& Šmilauer, P. (2003). Multivariate Analysis of Ecological Data using CANOCO. Cambridge Press.

Madsen, P.B., Morabowen, A., Andino, P., Espinosa, R., Cauvy-Fraunié, S., Dangles, O., et al. (2015). Altitudinal distribution limits of aquatic macroinvertebrates: an experimental test in a tropical alpine stream. Ecological Entomology 40, 629-638.

Magurran, A.E. (2013). Measuring Biological Diversity. John Wiley \& Sons.

Milner, A.M., \& Petts, G.E. (1994). Glacial rivers: physical habitat and ecology. Freshwater Biology 32, 295-307.

Milner, A.M., Brittain, J.E., Castella, E. \& Petts, G.E. (2001a). Trends of macroinvertebrate community structure in glacier-fed rivers in relation to environmental conditions: a synthesis. Freshwater Biology $46,1833-1847$.

Milner, A.M., Taylor, R.C., \& Winterbourn, M.J. (2001b). Longitudinal distribution of macroinvertebrates in two glacier-fed New Zealand rivers Freshwater Biology 46, 1765-1775.

Milner, A.M., Robertson, A.L., Monaghan, K.A., Veal, A.J., \& Flory, E.A. (2008). Colonization and development of an Alaskan stream community over 28 years. Frontiers in Ecology and the Environment 6, 413-419.

Milner, A.M., Brown, L.E., \& Hannah, D.M. (2009). Hydroecological response of river systems to shrinking glaciers. Hydrological Processes 23, 62-77.

Muhlfeld, C.C., Giersch, J.J., Hauer, F.R., Pederson, G.T., Luikart, G., Peterson, D.P., ... Fagre, D.B. (2011). Climate change links fate of glaciers and an endemic alpine invertebrate. Climatic Change 106, 337-345. DOI 10.1007/s10584-011-0057-1

Pearman, P.B., \& Weber, D. (2007). Common species determine richness patterns in biodiversity indicator taxa. Biological Conservation 138, 109-119.

Quenta, E., Molina-Rodriguez, J., Gonzales, K., Rebaudo, F., Casas, J., Jacobsen, D., \& Dangles, O. (2016). Direct and indirect effects of glaciers on aquatic biodiversity in high Andean peatlands. Global Change Biology 22, 3196-3205. https://doi.org/10.1111/ gcb. 13310
Rabinowitz, D., Rapp, J.K. \& Dixon, P.M. (1984). Competitive abilities of sparse grass species: means of persistence or cause of abundance. Ecology 65, 1144-1154.

Resh, V.H., Bêche, L.A., \& McElravy, E.P. (2005). How common are rare taxa in long-term benthic macroinvertebrate surveys? Journal of the North American Benthological Society 24, 976-989.

Robinson, C.T., Thompson, C., Lods-Crozet, B., \& Alther R. (2016). Chironomidae diversity in high elevation streams in the Swiss Alps. Fundamental and Applied Limnology 188, 201-213.

Siqueira, T., Bini, L.M., Roque, F.O., Marques Couceiro, S.R., Trivinho-Strixino, S., \& Cottenie, K. (2012). Common and rare species respond to similar niche processes in macroinvertebrate metacommunities. Ecography 35, 183-192.

Slemmons, K.E.H., Saros, J.E., \& Simon, K. (2013). The influence of glacial meltwater on alpine aquatic ecosystems: a review. Environmental science. Processes \& Impacts 15, 1794-806.

Straka, M., Syrovátka, V., \& Helešic, J. (2012). Temporal and spatial macroinvertebrate variance compared: crucial role of CPOM in a headwater stream. Hydrobiologia 686, 119-134.

Tagliaferro, M., \& Pascual, M. (2017). First spatio-temporal study of macroinvertebrates in the Santa Cruz River: a large glacial river about to be dammed without a comprehensive pre-impoundment study. Hydrobiologia 784, 35-49.

Tiegs, S.D., Costello, D.M., Isken, M.W., Woodward, G., McIntyre, P.B., Gessner, M.O., ... Zwart, J.A. (2019). Global patterns and drivers of ecosystem functioning in rivers and riparian zones. Science Advances 5(1), eaav0486. DOI: $10.1126 /$ sciadv.aav0486

Ulrich, W., \& Gotelli, N.J. (2007). Null model analysis of species nestedness patterns. Ecology 88, 1824-1831.

Wantzen, K.M., \& Wagner, R. (2006). Detritus processing by invertebrate shredders: a neotropical-temperate comparison. Journal of the North American Benthological Society 25, 216-232.

Wilhelm, L., Besemer, K., Fasching, C., Urich, T., Singer, G.A., Quince, C., \& Battin, T.J. (2014) Rare but active taxa contribute to community dynamics of benthic biofilms in glacier-fed streams. Environmental Microbiology 16, 2514-2524. DOI: $10.1111 / 1462-2920.12392$ 


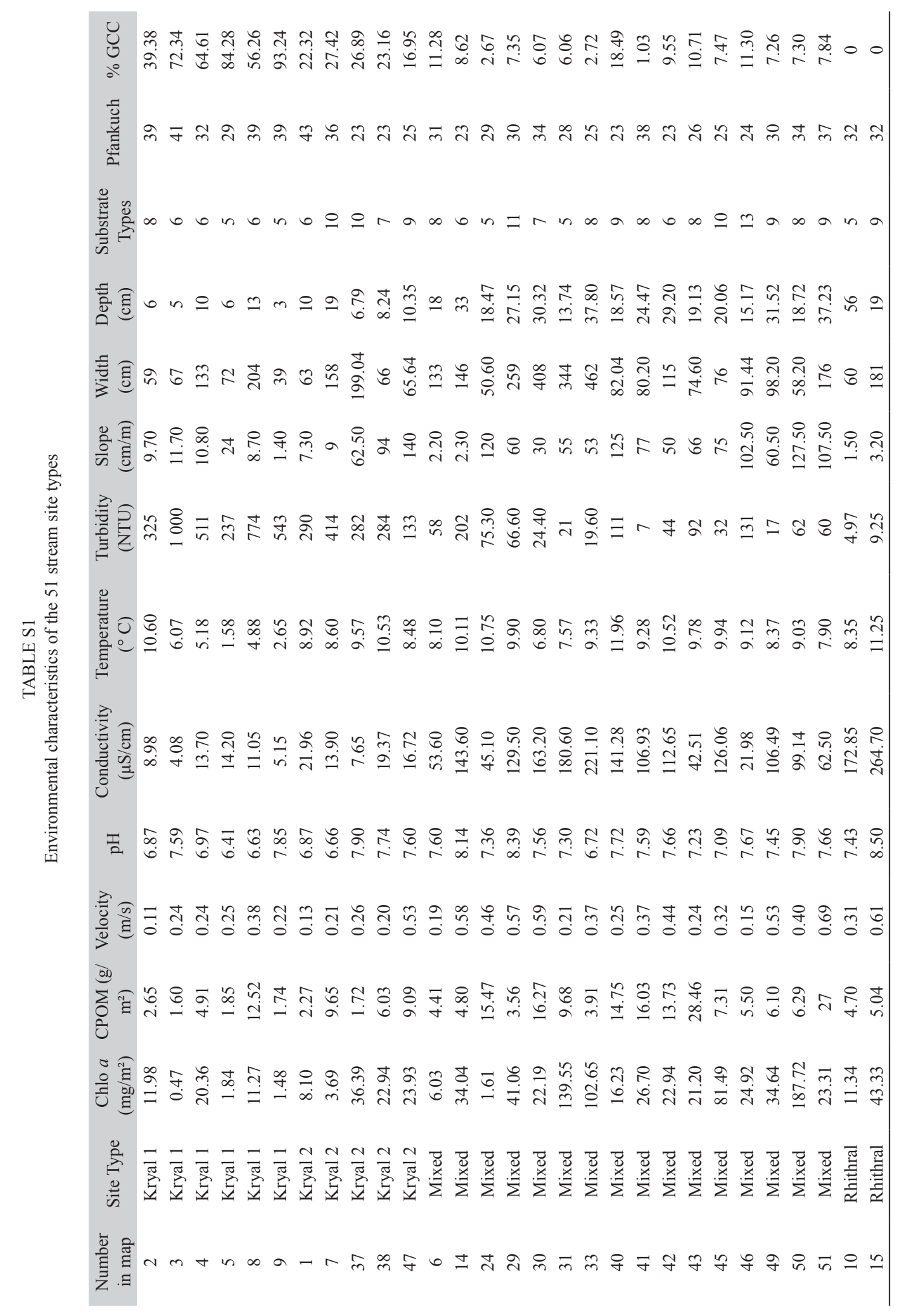




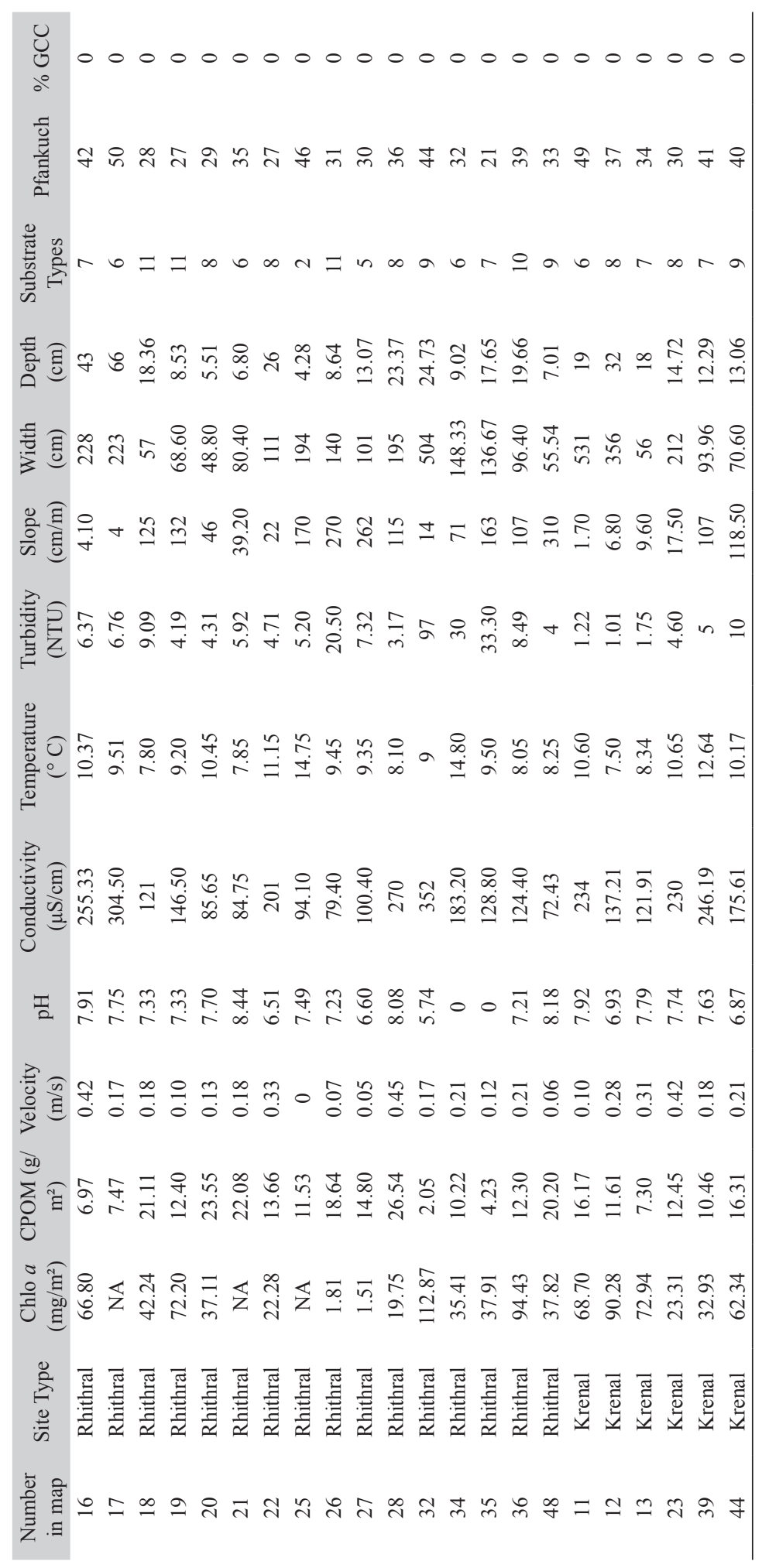




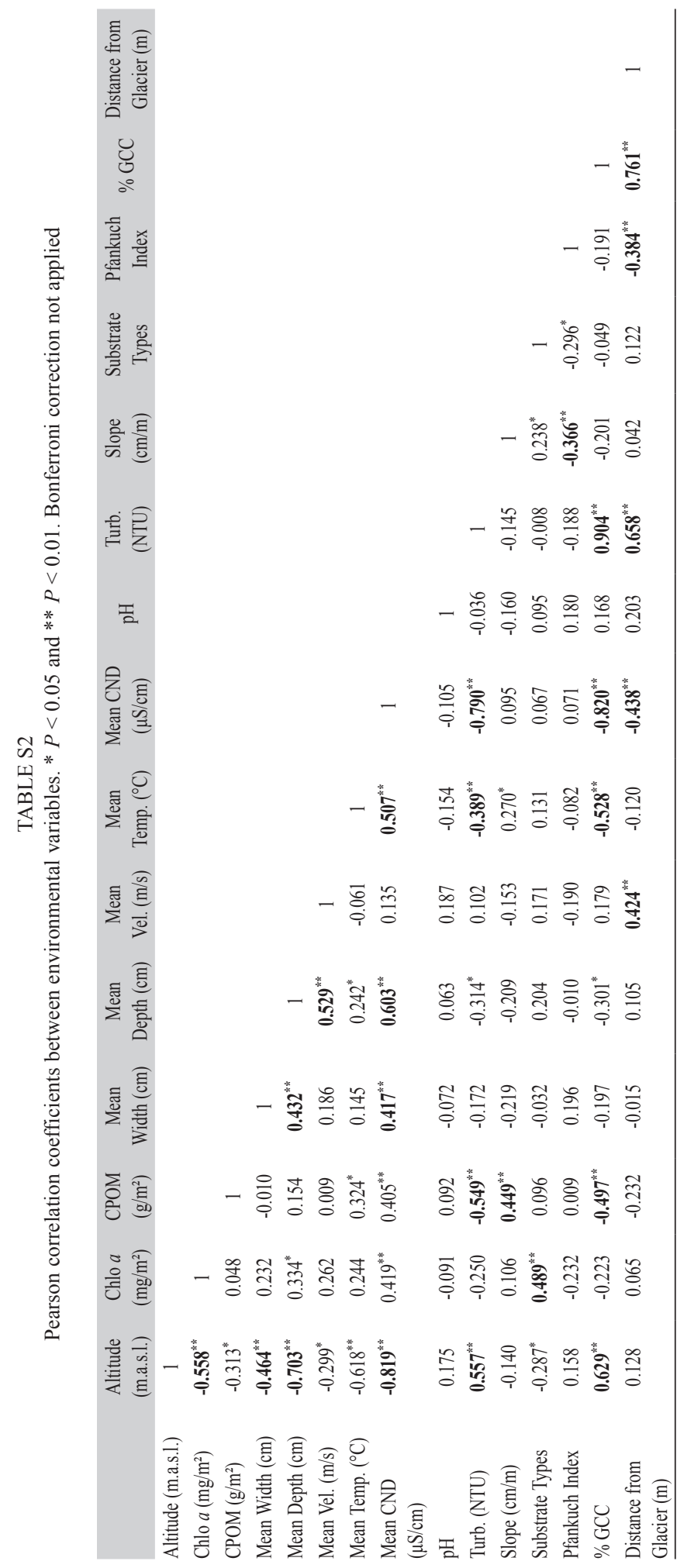


TABLE S3

Unique and common (shared) taxa found on each type of stream site. Bold taxa corresponds to taxa shared on all study sites. Values in parentheses correspond to the proportion of 82 total taxa found on the study

\begin{tabular}{|c|c|c|c|c|c|c|}
\hline Taxon & K1 & K2 & M & Rhithral & Krenal & Total \\
\hline \multicolumn{7}{|l|}{ Alluaudomyia sp. } \\
\hline \multicolumn{7}{|l|}{ Andesiops sp. } \\
\hline \multicolumn{7}{|l|}{ Anomalocosmoecus sp. } \\
\hline Atopsyche sp.1 & $\mathrm{X}$ & $X$ & $X$ & $X$ & $\mathrm{X}$ & \\
\hline Atopsyche sp.2 & & & & $\mathrm{X}$ & & \\
\hline \multicolumn{7}{|l|}{ Blepharicera sp.1 } \\
\hline \multicolumn{7}{|l|}{ Blepharicera sp. 2} \\
\hline Blepharicera sp.3 & & & $\mathrm{X}$ & & & \\
\hline Cailloma sp.1 & $\mathrm{X}$ & $\mathrm{X}$ & $\mathrm{X}$ & $\mathrm{X}$ & $\mathrm{X}$ & \\
\hline \multicolumn{7}{|l|}{ Cailloma sp. 2} \\
\hline Cailloma sp. 3 & & & $\mathrm{X}$ & & & \\
\hline \multicolumn{7}{|l|}{ Ceratopogonidae indet. } \\
\hline Chelifera sp. & $X$ & $X$ & $\mathrm{X}$ & $\mathrm{X}$ & $\mathrm{X}$ & \\
\hline \multicolumn{7}{|l|}{ Chironomidae indet. } \\
\hline \multicolumn{7}{|l|}{ Chironominae } \\
\hline \multicolumn{7}{|l|}{ Claudioperla sp. } \\
\hline \multicolumn{7}{|l|}{ Contulma sp. } \\
\hline Corixidae sp. & & & & $X$ & & \\
\hline \multicolumn{7}{|l|}{ Crambidae } \\
\hline \multicolumn{7}{|l|}{ Curculionidae sp1 } \\
\hline Curculionidae sp2 & & & & $\mathrm{X}$ & & \\
\hline Diamesinae Type 1 & $X$ & $X$ & $\mathrm{X}$ & $\mathrm{X}$ & $\mathrm{X}$ & \\
\hline \multicolumn{7}{|l|}{ Diamesinae Type 2} \\
\hline \multicolumn{7}{|l|}{ Dimecoenia sp. } \\
\hline \multicolumn{7}{|l|}{ Dugesiidae sp. } \\
\hline Dytiscidae sp. & $\mathrm{X}$ & & & & & \\
\hline Ephydridae sp. & & & & & $\mathrm{X}$ & \\
\hline \multicolumn{7}{|l|}{ Geranomyia sp. } \\
\hline \multicolumn{7}{|l|}{ Glossiphoniidae sp.1 } \\
\hline \multicolumn{7}{|l|}{ Glossiphoniidae sp.2 } \\
\hline Glossiphoniidae sp.3 & $\mathrm{X}$ & $\mathrm{X}$ & $\mathrm{X}$ & $\mathrm{X}$ & $\mathrm{X}$ & \\
\hline Glossiphoniidae sp.4 & & & & $\mathrm{X}$ & & \\
\hline Helichopsychidae sp. & & & & $\mathrm{X}$ & & \\
\hline Hemerodromia sp.1 & $\mathrm{X}$ & $\mathrm{X}$ & $\mathrm{X}$ & $\mathrm{X}$ & $X$ & \\
\hline \multicolumn{7}{|l|}{ Hyallela sp. } \\
\hline \multicolumn{7}{|l|}{ Hydracarina TOT } \\
\hline \multicolumn{7}{|l|}{ Hydroscaphidae sp. } \\
\hline Leucotabanus sp. & & & & $\mathrm{X}$ & & \\
\hline Limnophora sp.1 & $X$ & $X$ & $X$ & $\mathrm{X}$ & $X$ & \\
\hline \multicolumn{7}{|l|}{ Limnophora sp.2 } \\
\hline Limnophora sp.3 & & & & & & \\
\hline Limnophora sp.4 & & & & & & \\
\hline Limnophora sp.5 & & & & & $X$ & \\
\hline Limnophora sp.6 & & & & & $\mathrm{X}$ & \\
\hline Limnophora sp.7 & & & $\mathrm{X}$ & & & \\
\hline
\end{tabular}


TABLE S3 (Continued)

\begin{tabular}{|c|c|c|c|c|c|c|}
\hline Taxon & K1 & K2 & M & Rhithral & Krenal & Total \\
\hline Limoniidae indet. & & & & $\mathrm{X}$ & & \\
\hline \multicolumn{7}{|l|}{ Lumbriculidae } \\
\hline \multicolumn{7}{|l|}{ Lymnaeidae } \\
\hline Mayatrichia sp. & & & $X$ & & & \\
\hline Molophilus sp.1 & $\mathrm{X}$ & $X$ & $\mathrm{X}$ & $X$ & $\mathrm{X}$ & \\
\hline \multicolumn{7}{|l|}{ Molophilus sp.2 } \\
\hline \multicolumn{7}{|l|}{ Mortoniella sp. } \\
\hline \multicolumn{7}{|l|}{ Naididae sp.1 } \\
\hline \multicolumn{7}{|l|}{ Naididae sp.2 } \\
\hline Naididae sp.3 & & & & & $\mathrm{X}$ & \\
\hline \multicolumn{7}{|l|}{ Nectopsyche sp. } \\
\hline Nematoda & $X$ & $X$ & $X$ & $\mathrm{X}$ & $\mathrm{X}$ & \\
\hline \multicolumn{7}{|l|}{ Neoelmis sp.1 } \\
\hline \multicolumn{7}{|l|}{ Neoelmis sp.2 } \\
\hline \multicolumn{7}{|l|}{ Neotrichia sp.1 } \\
\hline \multicolumn{7}{|l|}{ Nepticulidae } \\
\hline Nonagria sp.1 & & & $\mathrm{X}$ & & & \\
\hline \multicolumn{7}{|l|}{ Ochrotrichia sp. } \\
\hline Orthocladinae & $X$ & $X$ & $\mathrm{X}$ & $\mathrm{X}$ & $\mathrm{X}$ & \\
\hline \multicolumn{7}{|l|}{ Ostracoda } \\
\hline \multicolumn{7}{|l|}{ Podonominae Type 1} \\
\hline \multicolumn{7}{|l|}{ Podonominae Type 2} \\
\hline Podonominae Type 3 & $X$ & $X$ & $X$ & $X$ & $\mathrm{X}$ & \\
\hline \multicolumn{7}{|l|}{ Podonominae Type 4} \\
\hline \multicolumn{7}{|l|}{ Prionocyphon sp.1 } \\
\hline \multicolumn{7}{|l|}{ Prionocyphon sp.2 } \\
\hline Prionocyphon sp.3 & & & $X$ & & & \\
\hline Schoenobiinae & & & $X$ & & & \\
\hline Simulium sp.1 & $\mathrm{X}$ & $X$ & $X$ & $X$ & $\mathrm{X}$ & \\
\hline \multicolumn{7}{|l|}{ Sphaeriidae } \\
\hline Staphylinidae sp. 1 & $\mathrm{X}$ & & & & & \\
\hline Staphylinidae sp. 2 & & $\mathrm{X}$ & & & & \\
\hline \multicolumn{7}{|l|}{ Stilobezzia sp.1 } \\
\hline \multicolumn{7}{|l|}{ Synclita sp.1 } \\
\hline Tanypodinae Type 1 & & & $X$ & & & \\
\hline Tipula sp. & & $X$ & & & & \\
\hline Trichocorixa sp. & & & & $\mathrm{X}$ & & \\
\hline Total Unique Taxa per group & $2(2.4 \%)$ & $2(2.4 \%)$ & $8(9.8 \%)$ & $8(9.8 \%)$ & $4(4.9 \%)$ & $24(29.3 \%)$ \\
\hline Total Common Taxa & & & & & & $13(15.9 \%)$ \\
\hline
\end{tabular}

